\title{
Crystal chemistry of cation-exchanged forms of epistolite-group minerals, Part I. Ag- and Cu-exchanged lomonosovite and Ag-exchanged murmanite
}

\author{
INNA S. LYKOVA, ${ }^{1, *}$, IGOR V. PEKOV ${ }^{1}$, NATALIA V. ZUBKOVA ${ }^{1}$, NIKITA V. CHUKANOV ${ }^{2}$, VASILIY O. YAPASKURT ${ }^{1}$, \\ NADEZHDA A. CHERVONNAYA ${ }^{2}$ and ANDREY A. ZOLOTAREV ${ }^{3}$ \\ ${ }^{1}$ Faculty of Geology, Moscow State University, Vorobievy Gory, 119991 Moscow, Russia \\ *Corresponding author, e-mail: innalykova@mail.ru \\ ${ }^{2}$ Institute of Problems of Chemical Physics RAS, Chernogolovka, Moscow Region 142432, Russia \\ ${ }^{3}$ Department of Crystallography, St. Petersburg State University, University Emb. 7/9, 199034 St. Petersburg, Russia
}

\begin{abstract}
The paper presents the first data on the crystal chemistry of the cation-exchanged forms of layered titanosilicates belonging to the epistolite group. It was found that these heterophyllosilicates have high exchange capacity and selectivity for cations of chalcophile elements ( $\mathrm{Ag}, \mathrm{Cu}$ and $\mathrm{Zn}$ ) and could be considered as potentially novel raw materials or, more likely, as possible prototypes of cation-selective synthetic microporous materials. The crystal structures of Ag- and $\mathrm{Cu}$-exchanged forms of lomonosovite and Ag-exchanged form of murmanite were studied by single-crystal X-ray diffraction. The topology of the main structural unit, the $\mathrm{HOH}$ block, remains unchanged in cation-exchanged forms as compared to the initial lomonosovite $\mathrm{Na}_{4} \mathrm{Ti}_{4}\left(\mathrm{Si}_{2} \mathrm{O}_{7}\right)_{2} \mathrm{O}_{4}$. $2 \mathrm{Na}_{3} \mathrm{PO}_{4}(P-1)$ and murmanite $\mathrm{Na}_{4} \mathrm{Ti}_{4}\left(\mathrm{Si}_{2} \mathrm{O}_{7}\right)_{2} \mathrm{O}_{4} \cdot 4 \mathrm{H}_{2} \mathrm{O}(P-1)$. In Ag-exchanged murmanite, Ag cations occupy two crystallographically non-equivalent positions: one in the heteropolyhedral $(H)$ sheet and another one in the octahedral $(O)$ sheet corresponding to the positions of $\mathrm{Na}$ in initial murmanite. The crystal structure of the Ag-exchanged form of lomonosovite is characterized by an increased unit-cell parameter $c$ and doubled parameter $b$ as compared to initial lomonosovite. Ten large-cation sites statistically occupied by $\mathrm{Ag}$ and $\mathrm{Na}$ correspond to the $\mathrm{Na}$ sites in the initial lomonosovite: six in the interlayer space, two in the $H$ sheet and two in the $O$ sheet. Silver significantly replaces $\mathrm{Na}$ in sites in the interlayer space and in the $O$ sheet, whereas sites in the $H$ sheet are less affected by the ion exchange. Unit-cell parameter $c$ of the $\mathrm{Cu}$-exchanged form of lomonosovite decreases by $3.58 \%$ as compared to the initial lomonosovite whereas $a$ and $b$ remain almost the same. The $\mathrm{Cu}$ cations occupy two crystallographically independent positions. The $\mathrm{Cu}(1)$ site, corresponding to the $\mathrm{Na}(3)$ site in the initial lomonosovite, is located in the interlayer space. The lowoccupancy $\mathrm{Cu}(2)$ site is located on the inversion centre in the $O$ sheet; this site is vacant in the initial lomonosovite. The $\mathrm{Cu}(2)$ site is surrounded by six $\mathrm{O}$ atoms forming an octahedron distorted due to the Jahn-Teller effect.
\end{abstract}

Key-words: lomonosovite; murmanite; heterophyllosilicate minerals; layered titanosilicate; microporous material; ion exchange; crystal structure.

\section{Introduction}

The ion-exchange properties of various natural microporous titano-, niobo- and zirconosilicates with structures based on zeolite-like heteropolyhedral frameworks have been actively studied during the last two decades, including the ion-exchange capacity, kinetic and crystal chemistry of their cation-exchanged forms. The obtained results found applications in both the industry and the geosciences (see, e.g., the reviews by Chukanov \& Pekov, 2005, and Pekov \& Chukanov, 2005). However, data on the layered titano- and niobosilicates as ion exchangers have not been reported until recently. Our studies show that heterophyllosillicate minerals belonging to the epistolite group prove to be the first known family of minerals that show strong affinity and selectivity in cation-exchange processes for chalcophile elements, including industrially important ones, whereas other, earlier studied silicate minerals demonstrated exchange selectivity to lithophile elements, in first place alkali and earth-alkali metals. Thus, these epistolite-group heterophyllosilicates could be considered as potentially novel raw materials or, more likely, as possible prototypes of cation-selective synthetic microporous materials.

Murmanite, ideally $\mathrm{Na}_{4} \mathrm{Ti}_{4}\left(\mathrm{Si}_{2} \mathrm{O}_{7}\right)_{2} \mathrm{O}_{4} \cdot 4 \mathrm{H}_{2} \mathrm{O}$, and lomonosovite, $\mathrm{Na}_{4} \mathrm{Ti}_{4}\left(\mathrm{Si}_{2} \mathrm{O}_{7}\right)_{2} \mathrm{O}_{4} \cdot 2 \mathrm{Na}_{3} \mathrm{PO}_{4}$, are layered titanosilicates (heterophyllosilicates) of the bafertisite mero-plesiotype series (Ferraris \& Gula, 2005). Their crystal structures are based on the heterophyllosilicate $\mathrm{HOH}$ block. The central $O$ sheet is composed by close-packed Na- and Ti-centred octahedra and is sandwiched between two $H$ sheets consisting of alternating $\left[\mathrm{Si}_{2} \mathrm{O}_{7}\right]$ groups, Ti-centred octahedra and 
Na-centred eight-fold polyhedra. The interlayer space contains $\mathrm{Na}^{+}$cations and $\mathrm{PO}_{4}{ }^{3-}$ groups in lomonosovite or $\mathrm{H}_{2} \mathrm{O}$ molecules in murmanite (Belov et al., 1977; Khalilov, 1989).

Murmanite was briefly described by Ramsay (1890) as an "unknown mineral \#3" from the Lovozero alkaline massif, Kola Peninsula, Russia, and later characterized as a new mineral species by Gutkova (1930). Lomonosovite was discovered at Lovozero by Gerasimovsky $(1945,1950)$. The morphological and chemical similarities of these minerals were obvious, and Borneman-Starynkevich (1946) showed that $\mathrm{Na}^{+}$and $\mathrm{PO}_{4}{ }^{3-}$ can easily be leached from the interlayer space of lomonosovite and replaced by $\mathrm{H}_{2} \mathrm{O}$ molecules which results in its transformation to murmanite.

The crystal structures of murmanite and lomonosovite were first examined by Khalilov et al. (1965) and repeatedly refined later (Rastsvetaeva et al., 1971; Belov et al., 1977; Rastsvetaeva \& Andrianov, 1986; Khalilov, 1989; Nemeth et al., 2005; Cámara et al., 2008). The history of these studies is given in detail by Cámara et al. (2008).

Murmanite and lomonosovite are common accessories, and, sometimes, the rock-forming minerals of specific peralkaline rocks and their pegmatites (Khomyakov, 1995). Despite the wide distribution of these minerals, the long history of their studies and the many experiments on the transformation of lomonosovite into murmanite, the ionexchange properties of these heterophyllosilicates have not been examined until recently. Only Selivanova (2012) briefly reported the ion exchange for murmanite in $\mathrm{KCl}$ solutions at room temperature: its K-exchanged form with 5.3-7.3 wt.\% $\mathrm{K}_{2} \mathrm{O}$ was obtained but no more data were published. We conducted the first systematic ion-exchange experiments with murmanite and lomonosovite in aqueous solutions of $\mathrm{K}, \mathrm{Rb}, \mathrm{Cs}, \mathrm{Ag}, \mathrm{Sr}, \mathrm{Cu}^{2+}, \mathrm{Ni}^{2+}$, and $\mathrm{Zn}$ salts and found that both minerals have high exchange capacity and selectivity for cations of some chalcophile elements, namely $\mathrm{Ag}, \mathrm{Cu}$ and $\mathrm{Zn}$ (Lykova et al., 2013a and b).

In this paper we report the crystal-chemical data on the $\mathrm{Ag}$ - and $\mathrm{Cu}$-exchanged forms of lomonosovite and the Agexchanged form of murmanite in comparison with the initial samples used for the ion-exchange experiments. The crystal chemistry of the Zn-exchanged forms of these heterophyllosilicates will be given, in comparison with natural zinc members of the epistolite group, in the companion paper, Part 2.

\section{Experimental procedure}

\section{Analytical methods}

The chemical composition of initial samples of murmanite and lomonosovite and their cation-exchanged forms was studied with a Jeol JSM-6480LV scanning electron microscope equipped with an energy dispersive X-ray spectrometer (EDS) INCA Energy-350 under the following conditions: operating voltage $25 \mathrm{kV}$, beam current 0.56 $\mathrm{nA}$. The following standards were used: lorenzenite $(\mathrm{Na} K \alpha, \operatorname{Si} K \alpha, \operatorname{Ti} K \alpha)$, diopside $(\mathrm{Ca} K \alpha, \operatorname{Mg} K \alpha)$, sanidine
$(\mathrm{K} K \alpha), \mathrm{AlPO}_{4}(\mathrm{Al} K \alpha, \mathrm{P} K \alpha), \mathrm{Cs}_{2} \mathrm{Nb}_{4} \mathrm{O}_{11}(\mathrm{Nb} L \alpha), \mathrm{MnCO}_{3}$ $(\mathrm{Mn} K \alpha), \mathrm{FeS}_{2}(\mathrm{Fe} K \alpha), \mathrm{Cu}_{3} \mathrm{VS}_{4}(\mathrm{Cu} K \alpha)$. and $\mathrm{Ag}_{2} \mathrm{Se}$ $(\mathrm{Ag} L \alpha)$. Iron and manganese oxidation states and $\mathrm{H}_{2} \mathrm{O}$ content were not determined directly.

The X-ray diffraction studies were carried out using single-crystal diffraction data collected for more than a hemisphere of the reciprocal space on a Bruker Kappa APEX II diffractometer equipped with a CCD detector for lomonosovite and murmanite and in a full sphere of the reciprocal space on a Bruker Kappa APEX DUO diffractometer equipped with a CCD detector for Ag- and $\mathrm{Cu}$-exchanged forms of lomonosovite and Ag-exchanged form of murmanite. The measured intensities were corrected for Lorentz, background, polarization and absorption effects.

The infrared absorption spectra were obtained using a Bruker Optics ALPHA FTIR spectrometer. The conditions were as follows: the wavenumber range from 360 to 3800 $\mathrm{cm}^{-1}$, the resolution of $4 \mathrm{~cm}^{-1}$, the number of scans of 16 . Powdered minerals were mixed with dry $\mathrm{KBr}$ and pelletized. The IR spectrum of an analogous pure $\mathrm{KBr}$ disk was subtracted from the overall spectrum.

\section{Initial samples and cation-exchange experiments}

Murmanite samples for our experiments originate from a hydrothermally altered peralkaline pegmatite at Severnyi (North) open pit, Umbozero mine, Mt. Alluaiv, Lovozero alkaline complex. Lomonosovite samples were collected from the huge unaltered peralkaline pegmatite Koashva-99 at Mt. Koashva, Khibiny alkaline complex (both Kola Peninsula, Russia). Murmanite forms lilac lamellar crystals up to $0.05 \times 2.5 \times 3 \mathrm{~cm}$ in the ussingite-microcline zone of a pegmatite. Lomonosovite occurs as dark-brown to almost black tabular crystals up to $0.2 \times 2 \times 3.5 \mathrm{~cm}$ associated with aegirine, pectolite, villiaumite and thermonatrite.

The ion-exchange experiments with murmanite were performed in Teflon containers at room temperature, at $60^{\circ} \mathrm{C}$ and at $90^{\circ} \mathrm{C}$ (Lykova et al., 2013a). As the experiment at $90^{\circ} \mathrm{C}$ showed the highest degree of exchange of $\mathrm{Na}$ for $\mathrm{Ag}$, this sample was chosen for the crystal structure study. A portion of 5-10 $\mathrm{mg}$ of the mineral (fraction $0.5-2$ $\mathrm{mm}$ ) was placed in $15 \mathrm{ml}$ of $1 \mathrm{~N}$ aqueous $\mathrm{AgNO}_{3}$ solution. Murmanite actively extracts silver from the solution with sodium displacement. The Ag-exchanged form of murmanite contains 3.3-3.7 Ag apfu (atoms per formula unit, henceforth calculated on the basis of $4 \mathrm{Si}+\mathrm{Al}$ ), whereas the initial sodium content was 2.7-2.9 apfu (Table 1). The possible schemes of the exchange are discussed in detail below. The reaction spreads over the entire volume of a grain within several hours.

Lomonosovite did not show the ion-exchange properties for $\mathrm{Ag}$ or $\mathrm{Cu}$ at $90^{\circ} \mathrm{C}$. For the experiments at $150^{\circ} \mathrm{C}$, sealed glass ampoules were used. In the experiments with $1 \mathrm{~N}$ aqueous $\mathrm{AgNO}_{3}$ solution, a novel Ag-rich phase (up to 58.8 wt. $\left.\% \mathrm{Ag}_{2} \mathrm{O}\right)$ was formed. The content of $\mathrm{P}($ apfu $)$ in this phase remains the same as in the initial lomonosovite 
Table 1. Chemical composition of murmanite (Mur) and product of its reaction with $\mathrm{AgNO}_{3}$ solution at $90^{\circ} \mathrm{C}$ (AgMur), lomonosovite (Lom) and products of its reactions with $\mathrm{AgNO}_{3}(\mathrm{AgLom})$ and $\mathrm{CuSO}_{4}(\mathrm{CuLom})$ solutions at $150^{\circ} \mathrm{C}$.

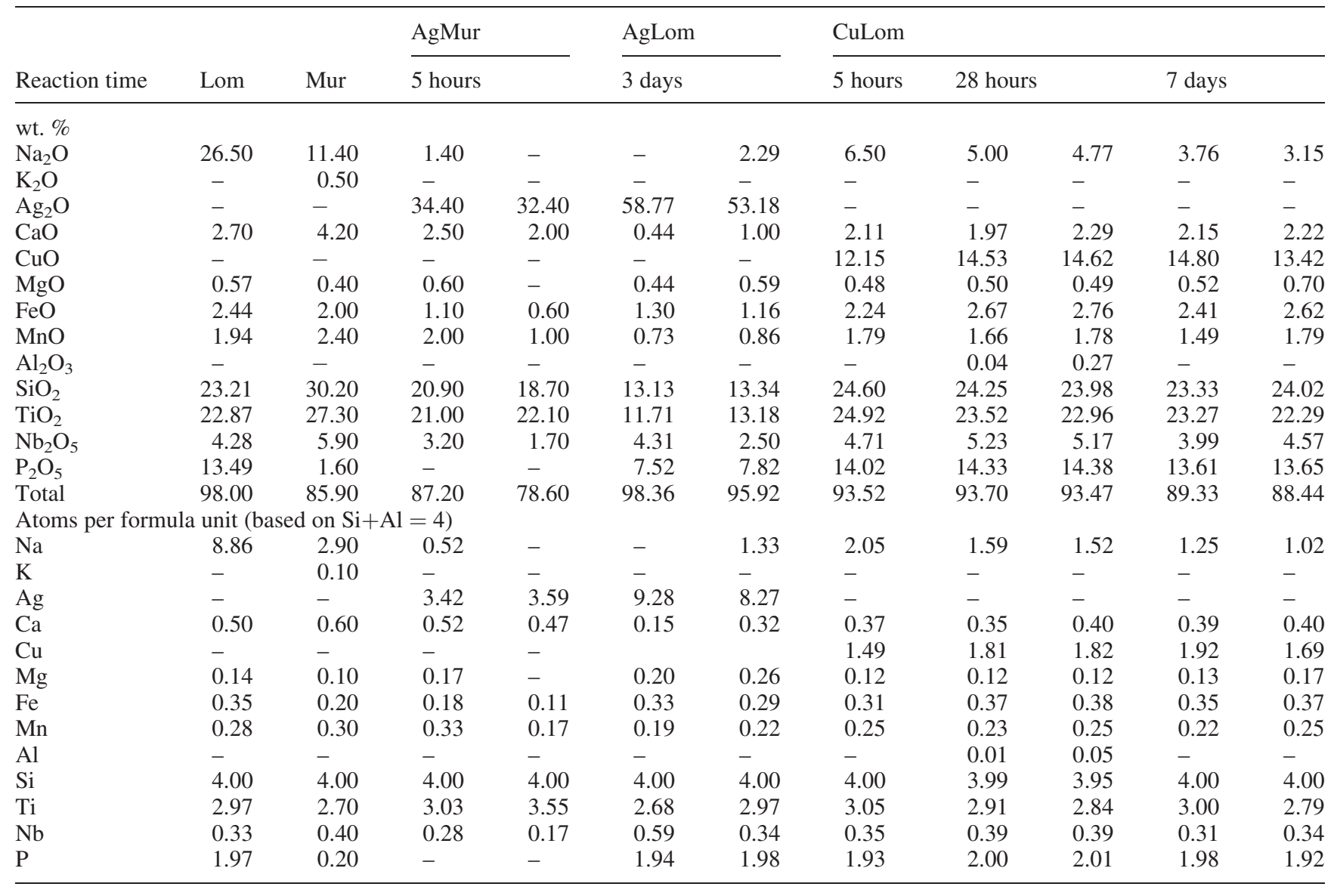

(Table 1). The replacement takes over $50-80 \%$ of the grains volume within several days (Fig. 1), and then the exchange rate drops significantly.

The products, mechanism and kinetics of the ionexchange reactions of murmanite and lomonosovite with $\mathrm{Ag}$ are discussed by Lykova et al. (2013b).

In the experiments with $1 \mathrm{~N}$ aqueous $\mathrm{CuSO}_{4}$ solution, a new phase with 1.5-1.9 apfu $\mathrm{Cu}$ develops within the first hours along the cleavage fractures of initial lomonosovite (Fig. 2a) and further spreads over the entire grains (Fig. 2b). The $\mathrm{P}$ content in this $\mathrm{Cu}$-exchanged form of lomonosovite remains the same as in initial lomonosovite (Table 1). Unfortunately, the acidic character of the $\mathrm{CuSO}_{4}$ solution causes partial dissolution of a thin peripheral zone of lomonosovite grains and damage (slight amorphization) of other products of the reaction. A rim of another phase, with higher Ti/Si ratio, is formed around lomonosovite grains (Fig. 2b).

\section{Single-crystal X-ray diffraction}

For single-crystal X-ray diffraction studies, products of the reactions with $\mathrm{AgNO}_{3}$ solution (during 3 days for lomonosovite and 5 hours for murmanite) and with $\mathrm{CuSO}_{4}$ solution

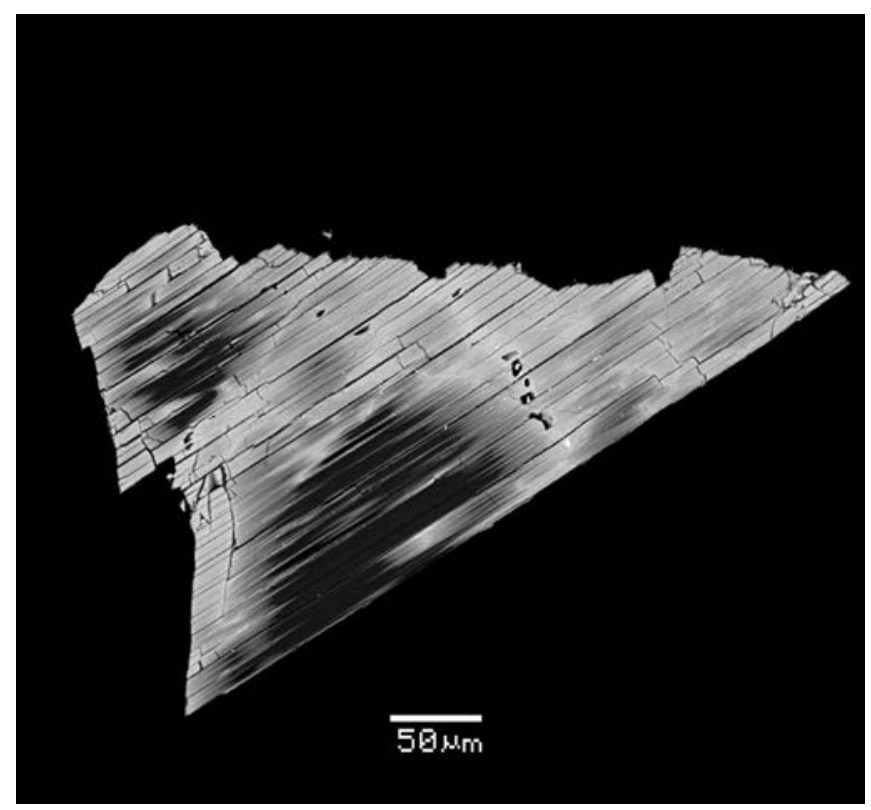

Fig. 1. Product of the reaction of lomonosovite with $1 \mathrm{~N}_{\mathrm{AgNO}_{3}}$ solution at $150^{\circ} \mathrm{C}$ during three days. Bright areas correspond to the Ag-exchanged form of lomonosovite, dark areas are relics of the initial mineral. Back-scattered electron (BSE) image. 


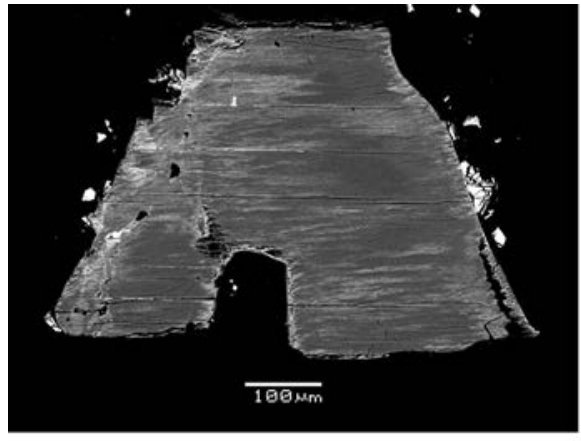

a)

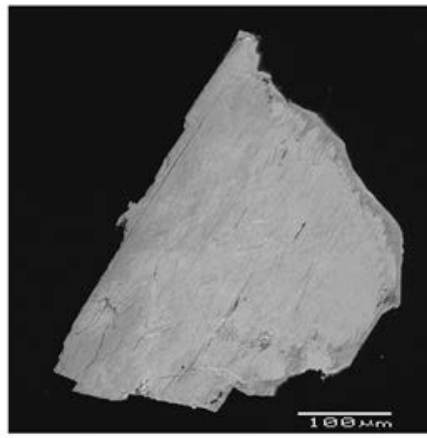

b)

Fig. 2. Products of the reaction of lomonosovite with $1 \mathrm{~N} \mathrm{CuSO}_{4}$ solution at $150^{\circ} \mathrm{C}$ during 5 (a) and 28 (b) hours. Bright areas correspond to the $\mathrm{Cu}$-exchanged form of lomonosovite, dark areas (a) are relics of the initial mineral. SEM (BSE) images.

(during 28 hours for lomonosovite), i.e., phases with a significant degree of exchange and minimum effects of amorphization and hydrolysis were used.

The crystal structures were solved by direct methods and refined by full-matrix least-squares techniques on $F^{2}$ in the space group $P-1$ using the SHELX-97 program package (Sheldrick, 2008). The crystal data, the details of the X-ray diffraction studies and the structure refinement parameters are given in Table 2, atom coordinates, equivalent displacement parameters, site occupancy factors or refined sitescatterings, bond-valence sum values (Brese \& O'Keeffe, 1991) and selected interatomic distances in Tables 3-12.
The crystal structures of the initial murmanite and lomonosovite were refined to $R=0.0665$ (1803 independent reflections with $I>2 \sigma(I)$ ) and to $R=0.0251$ (2346 independent reflections with $I>2 \sigma(I)$ ) (Table 2). The Ag-exchanged form of murmanite was refined on the basis of 1907 independent reflections with $I>2 \sigma(I)$ to $R$ $=0.0658$. The data sets for the exchanged samples of lomonosovite are of lower quality due to uneven Ag and $\mathrm{Cu}$ distribution. Slight hydration during the experiments could also contribute to the diffracted intensities. The final $R$ values are $12.28 \%$ for Ag-exchanged lomonosovite and $12.58 \%$ for $\mathrm{Cu}$-exchanged lomonosovite, respectively.

Table 2. Crystal data, data collection information and structure refinement details for murmanite (Mur), its Ag-exchanged form (AgMur), lomonosovite (Lom) and its $\mathrm{Ag}$ - and $\mathrm{Cu}$-exchanged forms (AgLom and CuLom respectively).

\begin{tabular}{|c|c|c|c|c|c|}
\hline Sample & Mur & AgMur & Lom & AgLom & CuLom \\
\hline Space group, Z & $P-1,1$ & $P-1,1$ & $P-1,1$ & $P-1,1$ & $P-1,1$ \\
\hline$a, \AA$ & $5.3741(6)$ & $5.4043(3)$ & $5.41160(10)$ & $5.4071(5)$ & $5.2653(19)$ \\
\hline$b, \AA$ & $7.0750(9)$ & $7.1687(4)$ & $7.1227(2)$ & $14.2614(12)$ & $7.153(3)$ \\
\hline$c, \AA$ & $12.1947(15)$ & $12.2593(8)$ & $14.4871(4)$ & $14.6246(14)$ & $13.969(5)$ \\
\hline$\alpha$ & $92.996(7)$ & $92.723(4)$ & $99.7395(16)$ & $99.477(3)$ & $100.050(9)$ \\
\hline$\beta$ & $107.758(8)$ & $107.881(4)$ & $96.5470(16)$ & $96.169(3)$ & $96.829(9)$ \\
\hline$\gamma$ & $90.100(8)$ & $90.398(4)$ & $90.2800(17)$ & $90.355(3)$ & $91.905(10)$ \\
\hline$V, \AA^{3}$ & $440.89(9)$ & $451.38(5)$ & $546.60(2)$ & $1105.58(17)$ & $513.6(3)$ \\
\hline$\lambda(\operatorname{Mo} K \alpha)(\AA), T(\mathrm{~K})$ & \multicolumn{5}{|c|}{$0.71073,293(2)$} \\
\hline Diffractometer & $\begin{array}{c}\text { Kappa APEX II } \\
\text { CCD }\end{array}$ & $\begin{array}{c}\text { Kappa APEX DUO } \\
\text { CCD }\end{array}$ & $\begin{array}{c}\text { Kappa APEX II } \\
\text { CCD }\end{array}$ & $\begin{array}{c}\text { Kappa APEX DUO } \\
\text { CCD }\end{array}$ & $\begin{array}{c}\text { Kappa APEX DUO } \\
\text { CCD }\end{array}$ \\
\hline Reflections collected & 3871 & 11157 & 5266 & 14940 & 7773 \\
\hline Unique reflections, $R_{\mathrm{int}}$ & $2151,0.0350$ & $2236,0.0578$ & $2702,0.0220$ & $5429,0.0295$ & $2083,0.0564$ \\
\hline Reflections with $I>2 \sigma(I)$ & 1803 & 1907 & 2346 & 4071 & 1727 \\
\hline Refinement on & \multicolumn{5}{|c|}{$F^{2}$} \\
\hline No. of refined parameters & 158 & 159 & 216 & 391 & 206 \\
\hline$R 1$ & 0.0665 & 0.0658 & 0.0251 & 0.1228 & 0.1258 \\
\hline $\mathrm{w} R 2_{\text {all }}\left(F^{2}\right)$ & 0.1747 & 0.1615 & 0.0606 & 0.2703 & 0.2992 \\
\hline GoF & 1.0768 & 1.154 & 1.050 & 1.103 & 1.156 \\
\hline$\Delta \rho_{\max } / \Delta \rho_{\min }\left(\mathrm{e} / \AA^{3}\right)$ & $1.572 /-0.916$ & $2.383 /-1.417$ & $0.381 /-0.554$ & $3.282 /-4.447$ & $3.208 /-1.672$ \\
\hline
\end{tabular}


Table 3. Atom coordinates $(x, y, z)$, equivalent thermal displacement parameters $\left(U_{\text {eq }}, \AA^{2}\right)$, site occupancy factors (s.o.f.) and bond-valence sums (BVS) in the structure of murmanite.

\begin{tabular}{lllllll}
\hline Atom & $x$ & $y$ & $z$ & $U_{\text {eq }}$ & s.o.f. $^{1}$ \\
\hline $\mathrm{Si}(1)$ & $0.9228(3)$ & $0.0515(2)$ & $0.26037(15)$ & $0.0236(4)$ & 1 & BVS $^{2}$ \\
$\mathrm{Si}(2)$ & $0.9481(3)$ & $0.6241(2)$ & $0.27720(15)$ & $0.0251(4)$ & 1 & 4.02 \\
$\mathrm{Ti}(1)$ & $0.41430(18)$ & $0.32665(14)$ & $0.23755(10)$ & $0.0271(4)$ & {$[24.0] \mathrm{Ti}_{0.89} \mathrm{Nb}_{0.11}$} \\
$\mathrm{Ti}(2)$ & $0.2765(2)$ & $0.88533(14)$ & $0.50506(9)$ & $0.0268(4)$ & {$[23.5] \mathrm{Ti}_{0.67} \mathrm{Mn}_{0.30} \mathrm{Nb}_{0.02}$} & 3.64 \\
$\mathrm{Na}(1)$ & $0.7332(7)$ & $0.6090(5)$ & $0.4895(3)$ & $0.0413(14)$ & {$[9.2] 0.835(15)$} & 4.28 \\
$\mathrm{Na}(2)$ & $0.3842(5)$ & $0.8295(4)$ & $0.2002(2)$ & $0.0349(9)$ & {$[11.5] \mathrm{Na}_{0.50} \mathrm{Ca}_{0.30}$} \\
$\mathrm{O}(1)$ & $0.5337(8)$ & $0.2982(6)$ & $0.3943(4)$ & $0.0304(10)$ & 1 & 1.02 \\
$\mathrm{O}(2)=(\mathrm{O}, \mathrm{OH})$ & $0.5025(8)$ & $0.8963(6)$ & $0.4128(4)$ & $0.0271(9)$ & 1 & 1 \\
$\mathrm{O}(3)$ & $0.9015(11)$ & $0.8250(6)$ & $0.2178(4)$ & $0.0405(12)$ & 1 & \\
$\mathrm{O}(4)$ & $0.0015(8)$ & $0.9336(6)$ & $0.5985(4)$ & $0.0248(9)$ & 1 & 1.71 \\
$\mathrm{O}(5)$ & $0.0606(9)$ & $0.6675(6)$ & $0.4161(4)$ & $0.0326(10)$ & 1 & \\
$\mathrm{O}(6)$ & $0.1384(10)$ & $0.1382(9)$ & $0.2110(5)$ & $0.0462(14)$ & 1 & 1.86 \\
$\mathrm{O}(7)$ & $0.6372(10)$ & $0.1336(8)$ & $0.2021(5)$ & $0.0463(14)$ & 1 & 1.92 \\
$\mathrm{O}(8)$ & $0.1635(10)$ & $0.5207(8)$ & $0.2316(5)$ & $0.0471(14)$ & 1 & 1.92 \\
$\mathrm{O}(9)$ & $0.6703(11)$ & $0.5219(9)$ & $0.2416(5)$ & $0.0493(15)$ & 1 & 1.99 \\
$\mathrm{O}(10)=\mathrm{H}_{2} \mathrm{O}$ & $0.2837(12)$ & $0.3450(8)$ & $0.0462(5)$ & $0.0485(13)$ & 1 & \\
$\mathrm{O}(11)=\mathrm{H}_{2} \mathrm{O}$ & $0.2509(12)$ & $0.7276(10)$ & $0.0060(6)$ & $0.0603(17)$ & 1 & 0.33 \\
\hline
\end{tabular}

${ }^{1}$ Basing on the $\mathrm{e}_{\mathrm{ref}}$ values (given in square brackets) and electron microprobe data we consider these occupancies of the sites, taking into account coordination polyhedra character and interatomic distances.

${ }^{2}$ BVS have been formally calculated taking into account s.o.f.

Table 4. Selected interatomic distances $(\AA)$ for murmanite.

\begin{tabular}{|c|c|c|c|c|c|}
\hline \multicolumn{3}{|c|}{$\operatorname{Ti}(1)$ - octahedron } & \multicolumn{3}{|c|}{$\operatorname{Ti}(2)$ - octahedron } \\
\hline \multirow[t]{6}{*}{$\operatorname{Ti}(1)$} & $-\mathrm{O}(1)$ & $1.844(5)$ & $\operatorname{Ti}(2)$ & $-\mathrm{O}(2)$ & $1.895(4)$ \\
\hline & $-\mathrm{O}(8)$ & $1.914(5)$ & & $-\mathrm{O}(1)$ & $1.908(5)$ \\
\hline & $-\mathrm{O}(6)$ & $1.933(5)$ & & $-\mathrm{O}(2)$ & $1.977(4)$ \\
\hline & $-\mathrm{O}(7)$ & $1.936(5)$ & & $-\mathrm{O}(5)$ & $1.987(5)$ \\
\hline & $-\mathrm{O}(9)$ & $1.936(5)$ & & $-O(4)$ & $2.120(4)$ \\
\hline & $-\mathrm{O}(10)$ & $2.233(6)$ & & $-\mathrm{O}(4)$ & $2.142(4)$ \\
\hline \multicolumn{2}{|c|}{$<\mathrm{Ti}(1)-\mathrm{O}>$} & 1.966 & $<\operatorname{Ti}($ & $>$ & 2.005 \\
\hline
\end{tabular}

\begin{tabular}{|c|c|c|c|c|c|}
\hline \multicolumn{3}{|c|}{$\mathrm{Si}(1)$ - tetrahedron } & \multicolumn{3}{|c|}{$\operatorname{Si}(2)$ - tetrahedron } \\
\hline \multirow[t]{4}{*}{$\operatorname{Si}(1)$} & $-\mathrm{O}(6)$ & $1.595(5)$ & $\operatorname{Si}(2)$ & $-\mathrm{O}(9)$ & $1.584(5)$ \\
\hline & $-\mathrm{O}(7)$ & $1.606(5)$ & & $-\mathrm{O}(8)$ & $1.593(5)$ \\
\hline & $-\mathrm{O}(4)$ & $1.640(5)$ & & $-\mathrm{O}(3)$ & $1.614(5)$ \\
\hline & $-\mathrm{O}(3)$ & $1.651(5)$ & & $-\mathrm{O}(5)$ & $1.628(5)$ \\
\hline \multicolumn{2}{|c|}{$<\mathrm{Si}(1)-\mathrm{O}>$} & 1.623 & \multicolumn{2}{|c|}{$<\mathrm{Si}(2)-\mathrm{O}>$} & 1.605 \\
\hline \multicolumn{3}{|c|}{$\mathrm{Na}(1)$ - octahedron } & \multicolumn{3}{|c|}{$\mathrm{Na}(2)$ - polyhedron } \\
\hline \multirow[t]{6}{*}{$\mathrm{Na}(1)$} & $-O(5)$ & $2.250(6)$ & $\mathrm{Na}(2)$ & $-\mathrm{O}(11)$ & $2.329(7)$ \\
\hline & $-\mathrm{O}(1)$ & $2.375(5)$ & & $-\mathrm{O}(2)$ & $2.493(5)$ \\
\hline & $-\mathrm{O}(5)$ & $2.417(6)$ & & $-\mathrm{O}(7)$ & $2.538(7)$ \\
\hline & $-\mathrm{O}(2)$ & $2.459(5)$ & & $-\mathrm{O}(6)$ & $2.573(7)$ \\
\hline & $-\mathrm{O}(1)$ & $2.510(6)$ & & $-\mathrm{O}(8)$ & $2.585(7)$ \\
\hline & $-\mathrm{O}(4)$ & $2.761(6)$ & & $-\mathrm{O}(9)$ & $2.647(7)$ \\
\hline \multirow{3}{*}{\multicolumn{2}{|c|}{$<\mathrm{Na}(1)-\mathrm{O}>$}} & 2.462 & & $-\mathrm{O}(3)$ & $2.668(6)$ \\
\hline & & & & $-\mathrm{O}(3)$ & $2.722(6)$ \\
\hline & & & $<\mathrm{Na}$ & $p>$ & 2.569 \\
\hline
\end{tabular}

However, in spite of relatively high $R$, reasonable interatomic distances (Tables 10 and 12), atom displacement parameters and bond valence sums (Tables 9 and 11) show that the obtained structure models are correct.

Unfortunately all tested crystals of $\mathrm{Cu}$-exchanged murmanite demonstrated a low quality that prevented the collection of data suitable for structure refinement.

\section{Results and discussion}

The main structural and topological features of lomonosovite and murmanite were discussed in the summarizing paper by Ferraris \& Gula (2005). We focus on the structural comparison of initial lomonosovite and murmanite with their cation-exchanged forms.

\section{Initial murmanite}

There are two distorted octahedra centred by $\operatorname{Ti}(2)$ and $\mathrm{Na}(1)$ in a 1:1 ratio in the octahedral $O$ sheet of the $\mathrm{HOH}$ block in the structure of initial murmanite (Fig. 3a). The $\mathrm{Ti}(2)$ site is Ti-dominant with $0.30 \mathrm{Mn}$ and $0.02 \mathrm{Nb}$. The $\mathrm{Na}(1)$ site is occupied solely by $\mathrm{Na}$ with $84 \%$ occupancy and $a<\mathrm{Na}(1)-\mathrm{O}>$ distance of $2.46 \AA$ (Tables 3-4). The composition of the heteropolyhedral $H$ sheet corresponds to the simplified formula $\left[\mathrm{NaTiSi}_{2} \mathrm{O}_{7}\right]^{-}$. It consists of the tetrahedral disilicate groups $\mathrm{Si}_{2} \mathrm{O}_{7}$ alternating with $\mathrm{Ti}(1)$ centred octahedra and $\mathrm{Na}(2)$-centred eight-fold polyhedra. "Pendent" vertices of $\mathrm{Ti}(1)$ - and $\mathrm{Na}(2)$-centred polyhedra $\left[\mathrm{O}(10)\right.$ and $\mathrm{O}(11)$ respectively] are occupied by $\mathrm{H}_{2} \mathrm{O}$ molecules. The Ti(1) site is occupied predominantly by $\mathrm{Ti}$ with admixture of heavy $\mathrm{Nb}$ (11\% of site occupancy). The $\mathrm{Ti}(1)$-centred octahedron is distorted: five short interatomic $\mathrm{Ti}(1)-\mathrm{O}$ distances vary from $1.844(5)$ to $1.936(5)$ $\AA$ whereas the sixth $\operatorname{Ti}(1)-\mathrm{O}(10)$ bond is $2.233(6) \AA$ long. $\mathrm{The} \mathrm{Na}(2)$ site is occupied by $0.50 \mathrm{Na}+0.30 \mathrm{Ca}+0.20 \square$ with a refined number of electrons $\left(e_{\text {ref }}\right)$ of 11.5 and an average $<\mathrm{Na}(2)-\mathrm{O}>$ distance of $2.57 \mathrm{~A}$ (Table 4). Thus both large cation sites in the initial murmanite contain vacancies. The most probable mechanism of charge compensation is partial protonation of the bridging oxygen in $\operatorname{Ti}(2)-\mathrm{O}(2)-\mathrm{Ti}(2)$. It is confirmed by bond-valence calculation for $\mathrm{O}(2)=1.71 v u$ (valence units; Table 3) and the 
Table 5. Atom coordinates $(x, y, z)$, equivalent thermal displacement parameters $\left(U_{\mathrm{eq}}, \AA^{2}\right)$, site occupancy factors (s.o.f.) and bond-valence sums (BVS) in the structure of Ag-exchanged form of murmanite.

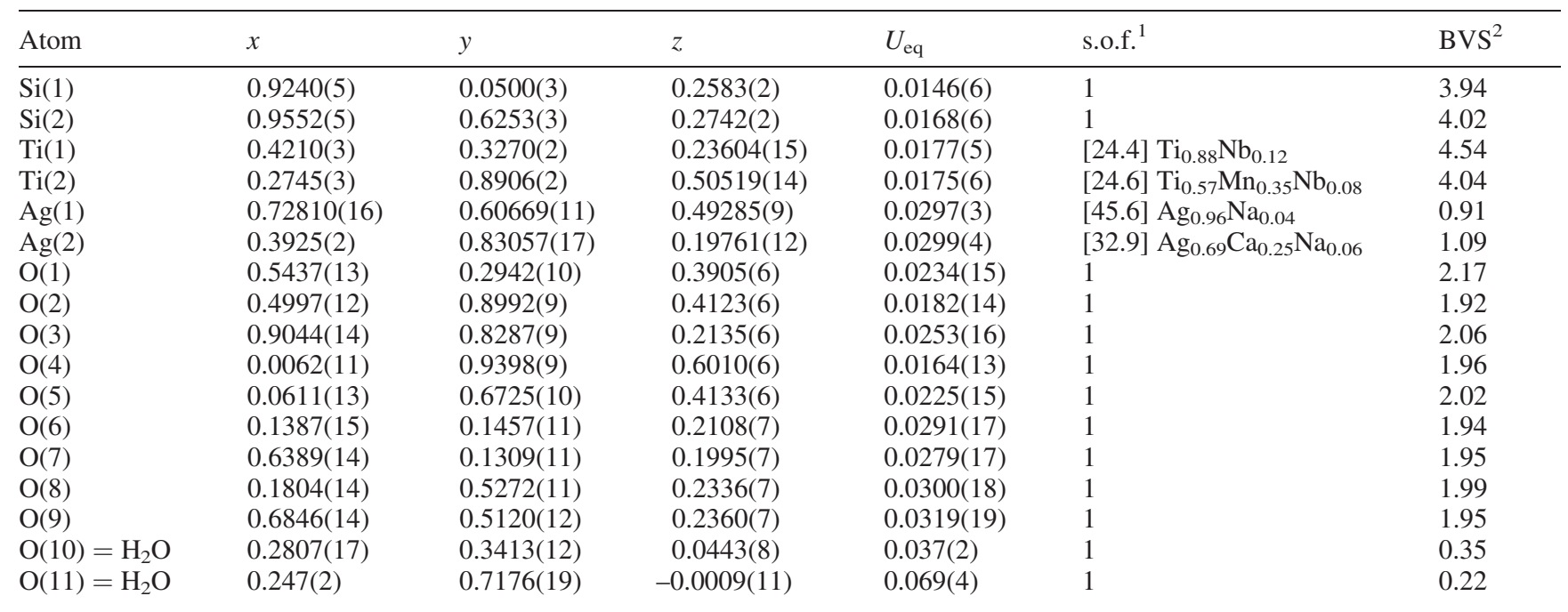

\footnotetext{
${ }^{1}$ Basing on the $\mathrm{e}_{\mathrm{ref}}$ values (given in square brackets) and electron microprobe data we consider these occupancies of the sites, taking into account coordination polyhedra character and interatomic distances.
}

${ }^{2}$ BVS have been formally calculated taking into account s.o.f.

Table 6. Selected interatomic distances $(\AA)$ for the Ag-exchanged form of murmanite.

\begin{tabular}{|c|c|c|c|c|c|}
\hline \multicolumn{3}{|c|}{ Ti(1) - octahedron } & \multicolumn{3}{|c|}{$\operatorname{Ti}(2)$ - octahedron } \\
\hline \multirow[t]{6}{*}{$\operatorname{Ti}(1)$} & $-\mathrm{O}(1)$ & $1.831(8)$ & $\mathrm{Ti}(2)$ & $-\mathrm{O}(2)$ & $1.907(7)$ \\
\hline & $-\mathrm{O}(6)$ & $1.938(7)$ & & $-\mathrm{O}(1)$ & $1.940(7)$ \\
\hline & $-\mathrm{O}(8)$ & $1.939(7)$ & & $-\mathrm{O}(2)$ & $1.963(7)$ \\
\hline & $-\mathrm{O}(9)$ & $1.939(7)$ & & $-\mathrm{O}(5)$ & $2.013(7)$ \\
\hline & $-\mathrm{O}(7)$ & $1.962(7)$ & & $-\mathrm{O}(4)$ & $2.107(7)$ \\
\hline & $-\mathrm{O}(10)$ & $2.245(9)$ & & $-\mathrm{O}(4)$ & $2.149(6)$ \\
\hline \multicolumn{2}{|c|}{$<\operatorname{Ti}(1)-\mathrm{O}>$} & 1.976 & \multicolumn{2}{|c|}{$<\mathrm{Ti}(2)-\mathrm{O}>$} & 2.013 \\
\hline \multicolumn{3}{|c|}{$\operatorname{Si}(1)$ - tetrahedron } & \multicolumn{3}{|c|}{$\operatorname{Si}(2)$ - tetrahedron } \\
\hline \multirow[t]{4}{*}{$\overline{\mathrm{Si}(1)}$} & $-\mathrm{O}(7)$ & $1.612(7)$ & $\overline{\mathrm{Si}(2)}$ & $-\mathrm{O}(9)$ & $1.596(7)$ \\
\hline & $-\mathrm{O}(6)$ & $1.612(7)$ & & $-\mathrm{O}(8)$ & $1.604(7)$ \\
\hline & $-\mathrm{O}(4)$ & $1.646(7)$ & & $-\mathrm{O}(5)$ & $1.641(8)$ \\
\hline & $-\mathrm{O}(3)$ & $1.646(7)$ & & $-\mathrm{O}(3)$ & $1.655(8)$ \\
\hline \multicolumn{2}{|c|}{$<\operatorname{Si}(1)-\mathrm{O}>$} & 1.629 & \multicolumn{2}{|c|}{$<\mathrm{Si}(2)-\mathrm{O}>$} & 1.624 \\
\hline \multicolumn{3}{|c|}{$\operatorname{Ag}(1)$ - octahedron } & \multicolumn{3}{|c|}{$\operatorname{Ag}(2)$ - polyhedron } \\
\hline \multirow[t]{6}{*}{$\operatorname{Ag}(1)$} & $-\mathrm{O}(5)$ & $2.350(7)$ & \multirow[t]{8}{*}{$\overline{\operatorname{Ag}(2)}$} & $-\mathrm{O}(11)$ & $2.414(14)$ \\
\hline & $-\mathrm{O}(1)$ & $2.432(7)$ & & $-O(7)$ & $2.519(8)$ \\
\hline & $-\mathrm{O}(5)$ & $2.464(7)$ & & $-\mathrm{O}(2)$ & $2.538(7)$ \\
\hline & $-\mathrm{O}(2)$ & $2.525(7)$ & & $-\mathrm{O}(8)$ & $2.570(8)$ \\
\hline & $-\mathrm{O}(1)$ & $2.553(7)$ & & $-\mathrm{O}(6)$ & $2.675(8)$ \\
\hline & $-\mathrm{O}(4)$ & $2.854(6)$ & & $-\mathrm{O}(3)$ & $2.703(7)$ \\
\hline \multirow{3}{*}{\multicolumn{2}{|c|}{$<\mathrm{Ag}(1)-\mathrm{O}>$}} & 2.530 & & $-\mathrm{O}(3)$ & $2.713(7)$ \\
\hline & & & & $-\mathrm{O}(9)$ & $2.762(9)$ \\
\hline & & & \multicolumn{2}{|c|}{$<\mathrm{Ag}(2)-\mathrm{O}>$} & 2.61 \\
\hline
\end{tabular}

presence of a weak shoulder at $3530 \mathrm{~cm}^{-1}$ in the IR spectrum of initial murmanite, corresponding to $\mathrm{O}-\mathrm{H}$ stretching vibrations of basic $\mathrm{OH}$ groups (Fig. 4).
The formula of murmanite obtained from the structural refinement is $\left\{\mathrm{Na}_{1.68}\left(\mathrm{Ti}_{1.36} \mathrm{Mn}_{0.60} \mathrm{Nb}_{0.04}\right)\right\}\left\{\mathrm{Na}_{1.00} \mathrm{Ca}_{0.60}\right.$ $\left.\left(\mathrm{Ti}_{1.78} \mathrm{Nb}_{0.22}\right)\left[\mathrm{Si}_{2} \mathrm{O}_{7}\right]_{2}\right\} \mathrm{O}_{2}(\mathrm{O}, \mathrm{OH})_{2}\left(\mathrm{H}_{2} \mathrm{O}\right)_{4}$ in which the contents of the $O$ and $H$ sheets are shown in braces.

\section{Ag-exchanged murmanite}

The crystal structure of the Ag-exchanged form of murmanite is characterized by slightly increased unit-cell parameters (Table 2) compared to the initial form, whereas the topology of the main structural $\mathrm{HOH}$ block remains unchanged. The Ag cations occupy two crystallographically non-equivalent positions $\operatorname{Ag}(1)$ and $\operatorname{Ag}(2)$ : one in the $O$ and another in the $H$ sheet, corresponding to the positions of $\mathrm{Na}(1)$ and $\mathrm{Na}(2)$, respectively, in the initial murmanite (Fig. 3b). There are no Ag sites in the interlayer space. The $\operatorname{Ag}(1)$ site is Ag-dominant with a small admixture of $\mathrm{Na}$ (4\% of site occupancy). The $\operatorname{Ag}(2)$ site is occupied by $0.69 \mathrm{Ag}+0.25 \mathrm{Ca}+0.06 \mathrm{Na}\left(e_{\text {ref }}=32.9\right.$, Table 5). The exchange of $\mathrm{Na}$ for $\mathrm{Ag}$ results in an increase in size of both polyhedra: average distances in them are $\langle\mathrm{Ag}(1)-\mathrm{O}\rangle=2.53 \AA$ and $\langle\mathrm{Ag}(2)-\mathrm{O}\rangle=2.61 \AA$ (Table 6). Unlike the initial murmanite, both large-cation sites in its Ag-exchanged form are fully occupied. The $\mathrm{Ag}^{+}$ ion actively replaces $\mathrm{Na}^{+}$and occupies also vacancies, whereas bivalent $\mathrm{Ca}$ is rigidly fixed in its site and remains inert during the reaction.

Thus, besides the "classic" exchange scheme $\mathrm{Na}^{+} \rightarrow$ $\mathrm{Ag}^{+}$, the two following ones can be hypothesized: $\square+$ $\mathrm{OH}^{-} \rightarrow \mathrm{Ag}^{+}+\mathrm{O}^{2-}$ and/or $\square+\mathrm{H}_{2} \mathrm{O} \rightarrow \mathrm{Ag}^{+}+\mathrm{OH}^{-}$. This is confirmed by the IR spectroscopy data and bond-valence calculations (Table 5). In the IR spectrum of the Ag-exchanged form of murmanite (Fig. 4) the shoulder at $3530 \mathrm{~cm}^{-1}$ corresponding to $\mathrm{O}-\mathrm{H}$ stretching vibrations of 
Table 7. Atom coordinates $(x, y, z)$, equivalent thermal displacement parameters $\left(U_{\mathrm{eq}}, \AA^{2}\right)$, site occupancy factors (s.o.f.) and bond-valence sums (BVS) in the structure of lomonosovite.

\begin{tabular}{|c|c|c|c|c|c|c|}
\hline Atom & $x$ & $y$ & $z$ & $U_{\text {eq }}$ & s.o.f. ${ }^{1}$ & $\mathrm{BVS}^{2}$ \\
\hline $\operatorname{Si}(1)$ & $0.64867(11)$ & $0.63898(8)$ & $0.19827(4)$ & $0.00775(13)$ & 1 & 4.12 \\
\hline $\mathrm{Si}(2)$ & $0.66524(11)$ & $0.20257(8)$ & $0.17705(4)$ & $0.00806(13)$ & 1 & 3.91 \\
\hline $\operatorname{Ti}(1)$ & $0.16434(6)$ & $0.92582(5)$ & $0.21680(2)$ & $0.00713(12)$ & {$[23.3] \mathrm{Ti}_{0.93} \mathrm{Nb}_{0.07}$} & 4.35 \\
\hline $\operatorname{Ti}(2)$ & $0.23049(7)$ & $0.61282(5)$ & $0.00733(2)$ & $0.01129(12)$ & {$[24.3] \mathrm{Ti}_{0.67} \mathrm{Mn}_{0.25} \mathrm{Nb}_{0.08}$} & 3.75 \\
\hline $\mathrm{P}$ & $0.17793(10)$ & $0.22359(7)$ & $0.43296(4)$ & $0.01005(13)$ & 1 & 4.74 \\
\hline $\mathrm{Na}(1)$ & $0.75680(17)$ & $0.88214(13)$ & $-0.00408(7)$ & $0.0242(2)$ & 1 & 1.08 \\
\hline $\mathrm{Na}(2)$ & $0.17170(18)$ & $0.41494(13)$ & $0.23406(6)$ & $0.0192(2)$ & 1 & 1.11 \\
\hline $\mathrm{Na}(3)$ & $0.68054(15)$ & $-0.02649(10)$ & $0.35917(5)$ & $0.0155(3)$ & {$[12.7] \mathrm{Na}_{0.70} \mathrm{Ca}_{0.25}$} & 1.23 \\
\hline $\mathrm{Na}(4)$ & $0.6760(2)$ & $0.46015(14)$ & $0.39794(7)$ & $0.0231(2)$ & 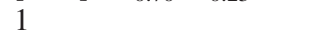 & 1.04 \\
\hline $\mathrm{Na}(5)$ & $0.7634(2)$ & $0.26184(13)$ & $0.58609(7)$ & $0.0236(2)$ & 1 & 1.03 \\
\hline $\mathrm{O}(1)$ & $0.1282(3)$ & $0.8352(2)$ & $0.09213(11)$ & $0.0154(3)$ & 1 & 2.16 \\
\hline $\mathrm{O}(2)$ & $0.0892(3)$ & $0.4227(2)$ & $0.07048(10)$ & $0.0134(3)$ & 1 & 1.92 \\
\hline $\mathrm{O}(3)$ & $0.6718(3)$ & $0.4273(2)$ & $0.23035(10)$ & $0.0134(3)$ & 1 & 2.21 \\
\hline $\mathrm{O}(4)$ & $0.4051(3)$ & $0.3919(2)$ & $-0.08356(10)$ & $0.0136(3)$ & 1 & 1.93 \\
\hline $\mathrm{O}(5)$ & $0.3600(3)$ & $0.8051(2)$ & $-0.06517(10)$ & $0.0131(3)$ & 1 & 2.08 \\
\hline $\mathrm{O}(6)$ & $0.4157(3)$ & $0.7336(2)$ & $0.24935(10)$ & $0.0119(3)$ & 1 & 2.03 \\
\hline $\mathrm{O}(7)$ & $-0.0950(3)$ & $0.7506(2)$ & $0.24569(11)$ & $0.0139(3)$ & 1 & 1.89 \\
\hline $\mathrm{O}(8)$ & $0.4347(3)$ & $0.1026(2)$ & $0.21052(12)$ & $0.0203(4)$ & 1 & 2.02 \\
\hline $\mathrm{O}(9)$ & $-0.0750(3)$ & $0.1199(2)$ & $0.21500(12)$ & $0.0189(4)$ & 1 & 2.17 \\
\hline $\mathrm{O}(10)$ & $0.2342(3)$ & $0.0337(2)$ & $0.36764(11)$ & $0.0152(3)$ & 1 & 1.94 \\
\hline $\mathrm{O}(11)$ & $0.3263(3)$ & $0.2287(2)$ & $0.53020(11)$ & $0.0209(4)$ & 1 & 1.93 \\
\hline $\mathrm{O}(12)$ & $0.2518(3)$ & $0.3981(2)$ & $0.39171(11)$ & $0.0186(4)$ & 1 & 1.90 \\
\hline $\mathrm{O}(13)$ & $-0.1006(3)$ & $0.2248(2)$ & $0.44241(12)$ & $0.0187(4)$ & 1 & 2.18 \\
\hline
\end{tabular}

${ }^{1}$ Basing on the $e_{\text {ref }}$ values (given in square brackets) and electron microprobe data we consider these occupancies of the sites, taking into account coordination polyhedra character and interatomic distances.

${ }^{2}$ BVS have been formally calculated taking into account s.o.f.

basic $\mathrm{OH}$ groups is stronger than that in the IR-spectrum of initial murmanite, whereas the bands in the range $3200-3400 \mathrm{~cm}^{-1}$ corresponding to more acidic $\mathrm{OH}$ groups and $\mathrm{H}_{2} \mathrm{O}$ molecules became weaker after exchange with Ag. The bond-valence sum of the $\mathrm{Ti}(2)-\mathrm{O}-\mathrm{Ti}(2)$ bridge oxygen $\mathrm{O}(2)$ in the Ag-exchanged form of murmanite is higher $(1.92 v u)$ than in the initial murmanite $(1.71 v u)$, which indicates possible deprotonation of the $\mathrm{OH}^{-}$groups.

The formula of the Ag-exchanged form of murmanite obtained from the structural refinement is $\left\{\mathrm{Ag}_{1.92} \mathrm{Na}_{0.08}\left(\mathrm{Ti}_{1.14} \mathrm{Mn}_{0.70} \mathrm{Nb}_{0.16}\right)\right\}\left\{\mathrm{Ag}_{1.38} \mathrm{Ca}_{0.50} \mathrm{Na}_{0.12}\right.$ $\left.\left(\mathrm{Ti}_{1.76} \mathrm{Nb}_{0.24}\right)\left[\mathrm{Si}_{2} \mathrm{O}_{7}\right]_{2}\right\} \mathrm{O}_{4}\left(\mathrm{H}_{2} \mathrm{O}, \mathrm{OH}\right)_{4}$, in which the contents of the $O$ and $H$ sheets are shown in braces. It corresponds to the empirical formula calculated on the basis of electron-microprobe data (Table 1).

\section{Initial lomonosovite}

In the initial lomonosovite the $\mathrm{HOH}$ block is the same as in murmanite (Fig. 5). The Ti(1) site in the $H$ sheet is occupied by $0.93 \mathrm{Ti}+0.07 \mathrm{Nb}$, and the $\mathrm{Ti}(2)$ site in the $O$ sheet contains $0.67 \mathrm{Ti}+0.25 \mathrm{Mn}+0.08 \mathrm{Nb}\left(e_{\text {ref }}=24.3\right.$; Table 7). The large cation sites $\mathrm{Na}(1)$ (average distance $<\mathrm{Na}(1)-\mathrm{O}>2.47 \AA)$ and $\mathrm{Na}(2)(<\mathrm{Na}(2)-\mathrm{O}>2.57 \AA$; Table 8 ) are fully occupied by Na. There are three large cation sites in the interlayer space with different coordination numbers: six-fold $\mathrm{Na}(3)$-centred polyhedron $(<\mathrm{Na}(3)-\mathrm{O}>2.45 \AA)$, four-fold $\mathrm{Na}(4)$-centred polyhedron
$(<\mathrm{Na}(4)-\mathrm{O}>2.30 \AA)$ and $\mathrm{Na}(5)$-centred five-fold polyhedron $(<\mathrm{Na}(5)-\mathrm{O}>2.41 \AA)$. The $\mathrm{Na}(4)$ and $\mathrm{Na}(5)$ sites are occupied solely by $\mathrm{Na}$ whereas $\mathrm{Na}(3)$ is Na-dominant with admixture of $\mathrm{Ca}$ ( $25 \%$ of the site occupancy). One $\mathrm{P}$ site in the interlayer space is fully occupied; the average $<\mathrm{P}-\mathrm{O}>$ distance in the $\mathrm{PO}_{4}$ tetrahedron is $1.54 \AA$. There are 13 anion sites $\mathrm{O}(1-13)$, occupied by $\mathrm{O}$ atoms which have bondvalence sums of 1.89-2.21 vu (Table 7).

The lomonosovite formula obtained from the structural refinement is $\left\{\mathrm{Na}_{3.40} \mathrm{Ca}_{0.50}\right\}\left\{\mathrm{Na}_{2.00}\left(\mathrm{Ti}_{1.34} \mathrm{Mn}_{0.50} \mathrm{Nb}_{0.16}\right)^{1}\right\}$ $\left\{\mathrm{Na}_{2.00}\left(\mathrm{Ti}_{1.86} \mathrm{Nb}_{0.14}\right)\left[\mathrm{Si}_{2} \mathrm{O}_{7}\right]_{2}\right\}\left(\mathrm{PO}_{4}\right)_{2} \mathrm{O}_{4}$, in which the contents of the interlayer space, $O$ and $H$ sheets are correspondingly given in braces.

\section{Ag-exchanged lomonosovite}

The Ag-exchanged form of lomonosovite is characterized by an increased $c$ parameter and a doubled $b$ parameter of the unit-cell as compared to the initial lomonosovite (Table 2). Yet the topology of the $\mathrm{HOH}$ block remains unchanged (Fig. 6a).

The crucial distinction from the initial lomonosovite is observed in the arrangement of $\mathrm{PO}_{4}$ tetrahedra. The $\mathrm{P}(1)-$ centred tetrahedron is regular with an average $<\mathrm{P}-\mathrm{O}\rangle$ distance of $1.54 \AA$, whereas another P site is split along $a$ into the two sub-sites $\mathrm{P}(2)$ and $\mathrm{P}\left(2^{\prime}\right)$. The occupancies have

\footnotetext{
${ }^{1}$ This site can also contain minor admixture of $\mathrm{Fe}^{3+}$.
} 
Table 8. Selected interatomic distances ( $\mathrm{A}$ ) for lomonosovite.

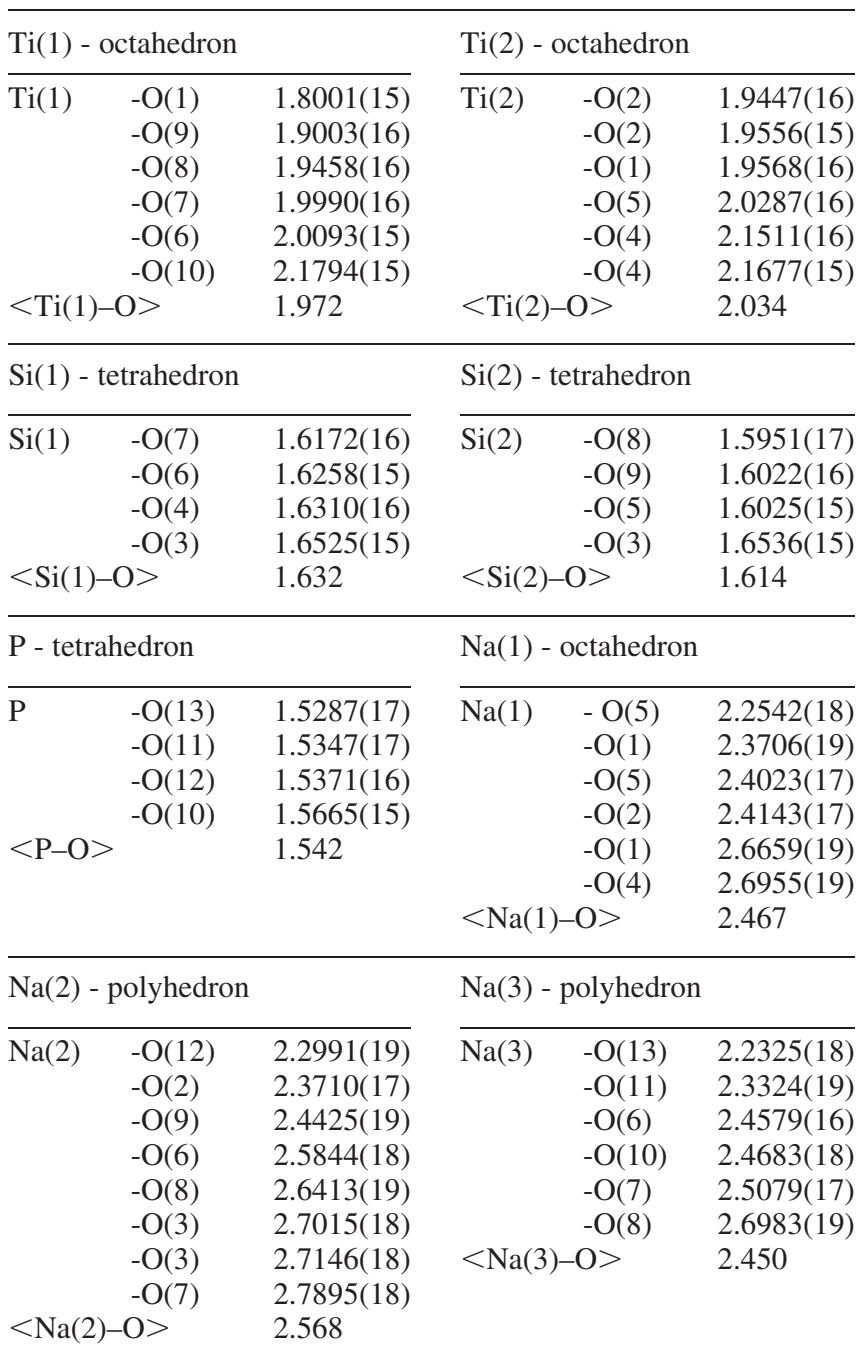

\begin{tabular}{|c|c|c|c|c|c|}
\hline \multicolumn{3}{|c|}{$\mathrm{Na}(4)$ - polyhedron } & \multicolumn{3}{|c|}{$\mathrm{Na}(5)$ - polyhedron } \\
\hline \multirow[t]{4}{*}{$\mathrm{Na}(4)$} & $-\mathrm{O}(13)$ & $2.2123(19)$ & $\mathrm{Na}(5)$ & $-\mathrm{O}(13)$ & $2.2605(19)$ \\
\hline & $-\mathrm{O}(11)$ & $2.2841(18)$ & & $-O(10)$ & $2.3146(18)$ \\
\hline & $-\mathrm{O}(12)$ & $2.324(2)$ & & $-\mathrm{O}(12)$ & $2.3920(18)$ \\
\hline & $-\mathrm{O}(3)$ & $2.3969(18)$ & & $-\mathrm{O}(11)$ & $2.408(2)$ \\
\hline \multirow{2}{*}{\multicolumn{2}{|c|}{$<\mathrm{Na}(4)-\mathrm{O}>$}} & 2.304 & & $-\mathrm{O}(6)$ & $2.6694(18)$ \\
\hline & & & $<\mathrm{Na}$ & $\mathrm{O}>$ & 2.409 \\
\hline
\end{tabular}

been refined to $47 \%$ and $42 \%$, respectively, for $\mathrm{P}(2)$ and $\mathrm{P}\left(2^{\prime}\right)$ (Table 9). This leads to the doubling of the $b$ parameter (Fig. 6b).

There are ten large-cation sites occupied by $\mathrm{Ag}$ and $\mathrm{Na}$ statistically replacing each other, corresponding to the $\mathrm{Na}$ sites in the initial lomonosovite: two in the $O$ sheet $[A(1 \mathrm{a})$ and $A(1 \mathrm{~b})]$, two in the $H$ sheet $[A(2 \mathrm{a})$ and $A(2 \mathrm{~b})]$ and six in the interlayer space $[A(3 \mathrm{a}-5 \mathrm{~b})]$. The $e_{\text {ref }}$ values found for these sites are: $A(1 \mathrm{a})-29.1, A(1 \mathrm{~b})-27.3, A(2 \mathrm{a})-14.4$, $A(2 b)$ - 14.1, A(3a) - 14.9, A(3b) - 15.1, A(4a) - 36.1, A(4b) $37.2, A(5 a)-29.0$ and $A(5 b)-30.1$. The collected singlecrystal X-ray diffraction data are an average between the initial lomonosovite and its Ag-exchanged form. Thus, the assignment of the multiple large-cation sites is clearly ambiguous. The obtained model of the crystal structure (a) confirms that $\mathrm{Ag}$ replaces $\mathrm{Na}$ and (b) shows preferable sites for $\mathrm{Ag}$ cations. Thus, sites $A(4 \mathrm{a})$ (average distance $<A(4 \mathrm{a})-\mathrm{O}>2.35 \AA)$ and $\mathrm{A}(4 \mathrm{~b})(<A(4 \mathrm{~b})-\mathrm{O}>2.52 / 2.51 \AA$ [calculated for polyhedra with bonds $A(4 \mathrm{~b})-\mathrm{O}(26) /$ $A(4 b)-\mathrm{O}\left(26^{\prime}\right)$, respectively]) are Ag-dominant, $A(1 \mathrm{a})$ $(<A(1 \mathrm{a})-\mathrm{O}>2.51 \AA), \quad A(1 \mathrm{~b})(<A(1 \mathrm{~b})-\mathrm{O}>2.50 \AA)$, $A(5 \mathrm{a})(<A(5 \mathrm{a})-\mathrm{O}>2.44 \AA)$ and $A(5 \mathrm{~b})(<A(5 \mathrm{~b})-\mathrm{O}>2.48$ $\AA$; Table 10) are half-occupied by $\mathrm{Ag}$, whereas positions in the $H$ sheet $A(2 \mathrm{a})$ and $A(2 \mathrm{~b})$ as well as the last two sites in the interlayer space, $A(3 a)$ and $A(3 b)$ are Na-dominant. Bond lengths $<A-\mathrm{O}>$ for the $A$ sites, containing significant amount of $\mathrm{Ag}$, are elongated as compared with the same sites in the initial lomonosovite. According to electron-microprobe data, sodium in the Ag-exchanged form of lomonosovite can be fully replaced by silver (Table 1), so it seems plausible that after the completion of the reaction Ag occupies all ten large cation sites, either solely or with a small admixture of Ca.

The $\mathrm{P}$ sites are partially vacant and we believe that ion exchange is accompanied by slight hydration with the replacement of the contact ion pairs $\left(\mathrm{Na}^{+}+\mathrm{PO}_{4}{ }^{3-}\right)$ in the interlayer space by $\mathrm{H}_{2} \mathrm{O}$ molecules according to the scheme: $3 \mathrm{Na}^{+}+\mathrm{PO}_{4}{ }^{3-} \rightarrow x \mathrm{H}_{2} \mathrm{O}+\square$.

Bond-valence sums for fully occupied anion sites coordinating $\mathrm{P}(1), \mathrm{P}(2)$ and $\mathrm{P}\left(2^{\prime}\right)$, namely $\mathrm{O}(14)$, $\mathrm{O}(18), \mathrm{O}(20), \mathrm{O}(21), \mathrm{O}(22), \mathrm{O}(25), \mathrm{O}(26)$ and $\mathrm{O}\left(26^{\prime}\right)$ are $1.84,1.70,1.73,1,75,1.85,1.58$ and $1.52 v u$, respectively (Table 9). This indicates possible admixture of $\mathrm{H}_{2} \mathrm{O}$ or $\mathrm{OH}^{-}$which could occupy these sites when $\mathrm{P}$ sites are vacant. It can also be confirmed by the presence in the IR spectrum of the Ag-exchanged form of lomonosovite of weak absorption bands of $\mathrm{O}-\mathrm{H}$ stretching vibrations $\left(3443 \mathrm{~cm}^{-1}\right)$ and $\mathrm{H}-\mathrm{O}-\mathrm{H}$ bending vibrations: 1680 (shoulder), 1647 and $1544 \mathrm{~cm}^{-1}$ (Fig. 7). The presence of three non-degenerate bands of $\mathrm{H}-\mathrm{O}-\mathrm{H}$ bending vibrations in the IR spectrum indicates the presence of three locally nonequivalent $\mathrm{H}_{2} \mathrm{O}$ molecules. There is no evidence of the presence of the $\mathrm{PO}_{3} \mathrm{OH}$ groups in the IR spectrum (i.e. there are no absorption bands in the range from 1700 to $3000 \mathrm{~cm}^{-1}$, Fig. 7), which excludes possible admixture of $\mathrm{P}-\mathrm{OH}$ bonds.

It was initially supposed that the presence of bands corresponding to $\mathrm{O}-\mathrm{H}$ stretching and $\mathrm{H}-\mathrm{O}-\mathrm{H}$ bending vibrations in the IR spectrum could be caused by admixture of murmanite formed after lomonosovite during the experiment. However, there are no reflections that could be assigned to murmanite in the $\mathrm{X}$-ray powder-diffraction pattern of the Ag-exchanged form of lomonosovite, neither do reciprocal-space images reveal any contribution from a phase with the $c$ unit-cell parameter close to that of murmanite, i.e. with $c \approx 12.2 \AA$. Both patterns also show that no other layered titanosilicate with the $c$ parameter distinctly different from one of a lomonosovite-like phase, i.e. with $c=14.4-14.5 \AA$, is present in the studied sample.

The other 18 anion sites, $\mathrm{O}(1-13,15-17,19,24)$ are occupied solely by $\mathrm{O}^{2-}$.

The formula of the Ag-exchanged form of lomonosovite obtained from the structural refinement is $\left\{\mathrm{Ag}_{2.83} \mathrm{Na}_{2.28} \mathrm{Ca}_{0.20}\right\}$ 
Table 9. Atom coordinates $(x, y, z)$, equivalent thermal displacement parameters $\left(U_{\mathrm{eq}}, \AA^{2}\right)$, site occupancy factors (s.o.f.) and bond-valence sums (BVS) in the structure of the Ag-exchanged form of lomonosovite.

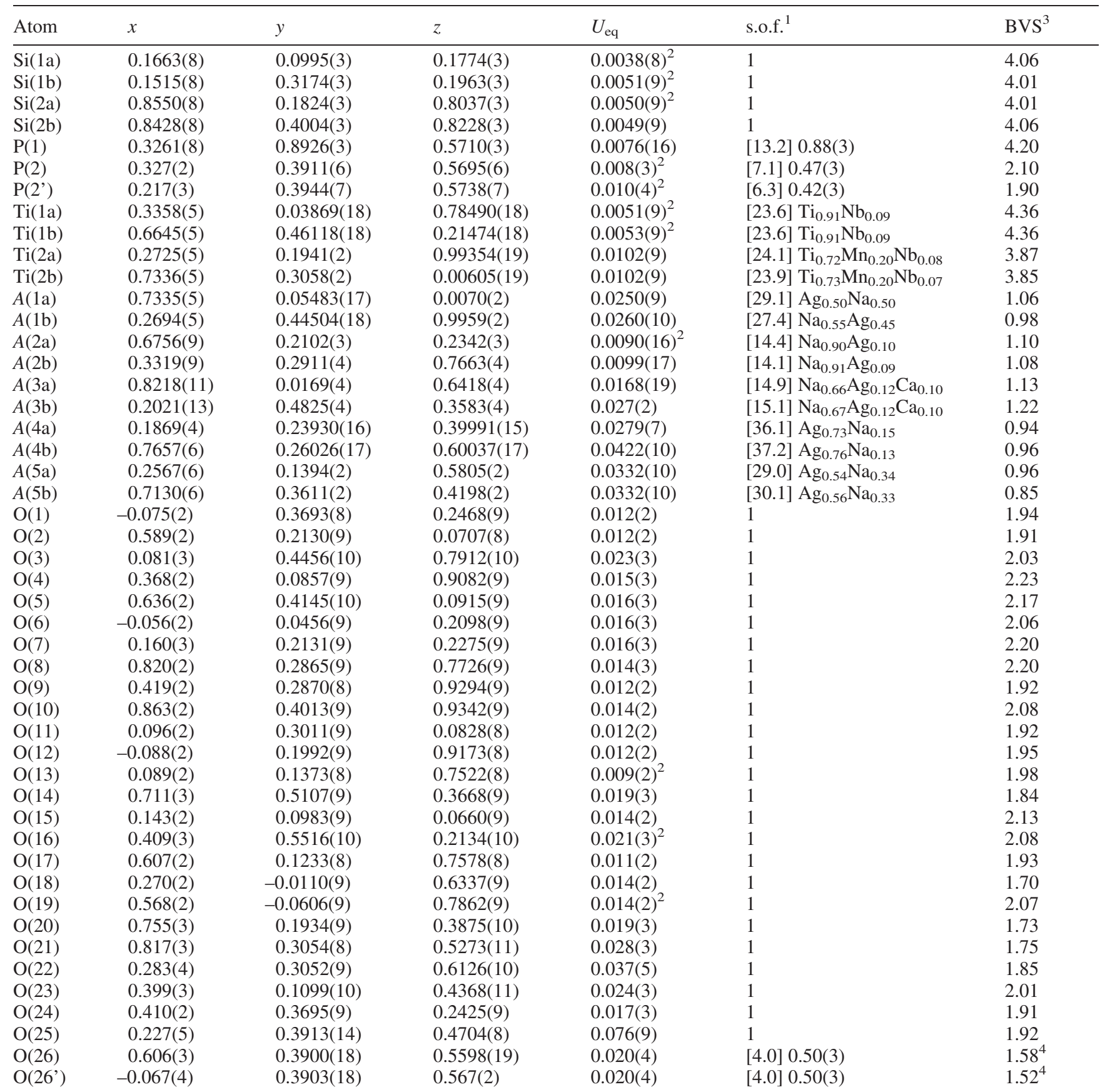

\footnotetext{
${ }^{1}$ Basing on the $\mathrm{e}_{\text {ref }}$ values (given in square brackets) and electron microprobe data we consider these occupancies of the sites, taking into account coordination polyhedra character and interatomic distances.

$\left\{\mathrm{Na}_{1.05} \mathrm{Ag}_{0.95}\left(\mathrm{Ti}_{1.45} \mathrm{Mn}_{0.20} \mathrm{Nb}_{0.15}\right)^{2}\right\}\left\{\mathrm{Na}_{1.81} \mathrm{Ag}_{0.19}\left(\mathrm{Ti}_{1.82} \mathrm{Nb}_{0.18}\right)\right.$ $\left.\left[\mathrm{Si}_{2} \mathrm{O}_{7}\right]_{2}\right\} \mathrm{O}_{2}\left(\mathrm{PO}_{4}\right)_{1.77}\left(\mathrm{H}_{2} \mathrm{O}\right)_{x}$, in which the contents of the interlayer space, $O$ and $H$ sheets are correspondingly given in braces.

\footnotetext{
${ }^{2}$ This site can also contain minor admixture of $\mathrm{Fe}^{3+}$.
}

\section{Cu-exchanged lomonosovite}

The Cu-exchanged form of lomonosovite is characterized by significantly decreased unit-cell parameter $c=$ $13.969(5) \AA$ as compared to the initial lomonosovite: 14.4871(4) $\AA$ (Table 2). The topology of the $\mathrm{HOH}$ 
Table 10. Selected interatomic distances $(\AA)$ for the Ag-exchanged form of lomonosovite.

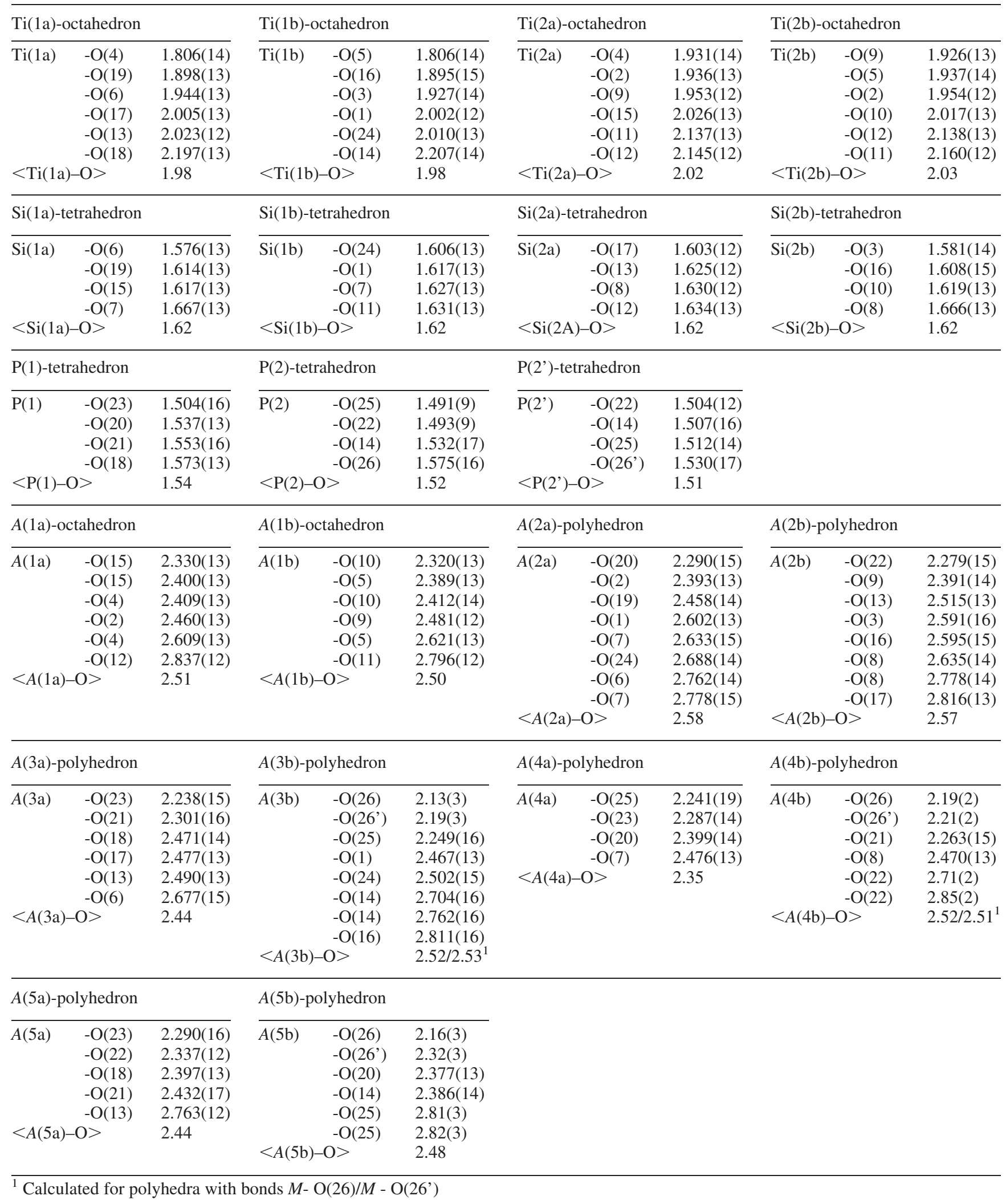

block remains unchanged. There are two Na-dominant sites in the $\mathrm{Cu}$-exchanged form of lomonosovite: $\mathrm{Na}(\mathrm{o})$ in the $O$-sheet corresponding to the $\mathrm{Na}(1)$ site in the initial lomonosovite and $\mathrm{Na}(\mathrm{i})$ in the interlayer space as a superposition of the vacant $\mathrm{Na}(2)$ site in the $H$ sheet and $\mathrm{Na}(4)$ and $\mathrm{Na}(5)$ sites in the interlayer space of the 
Table 11. Atom coordinates $(x, y, z)$, equivalent thermal displacement parameters $\left(U_{\text {eq }}, \AA^{2}\right)$, site occupancy factors (s.o.f.) and bond-valence sums (BVS) in the structure of the Cu-exchanged form of lomonosovite.

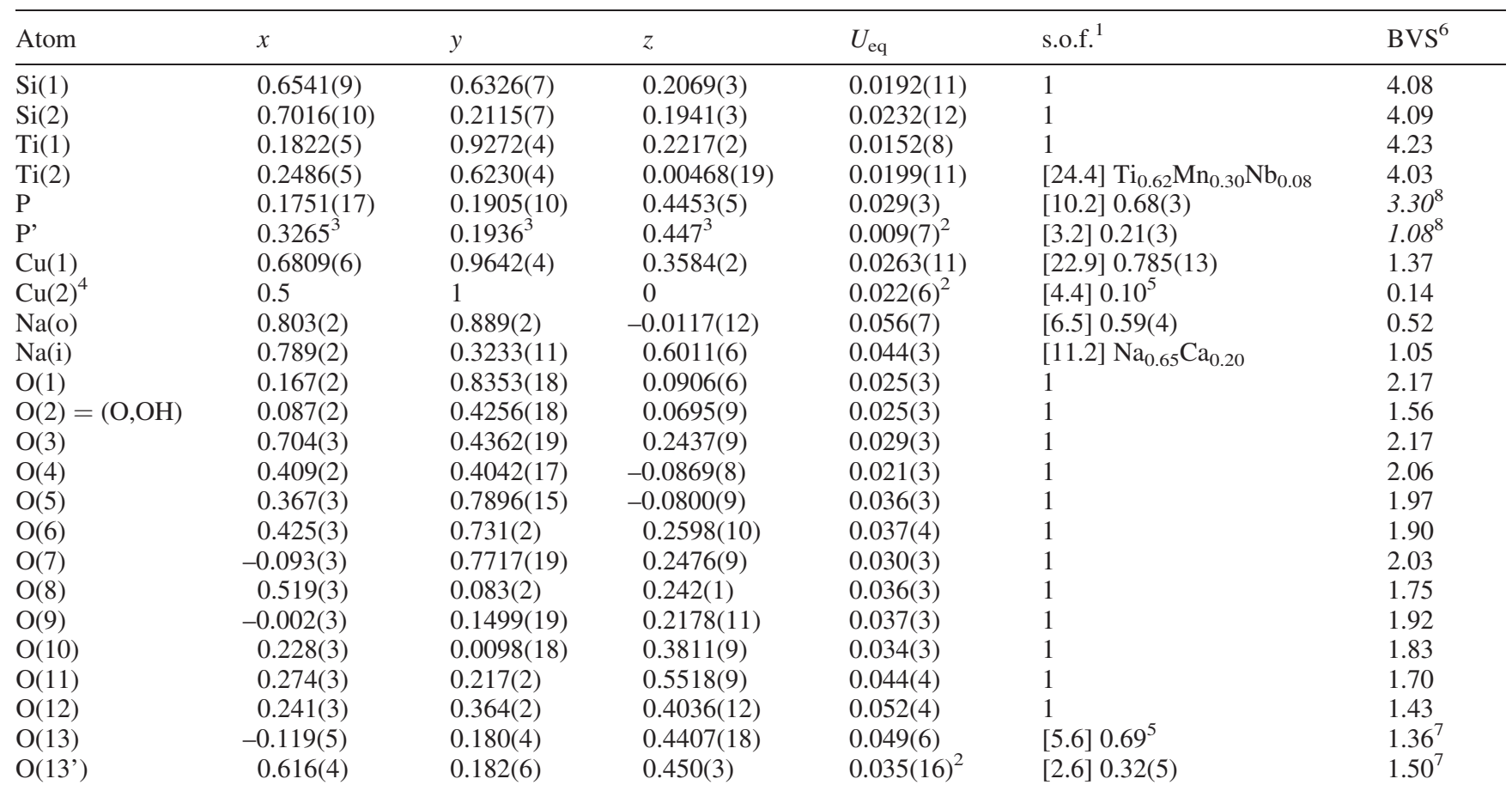

\footnotetext{
${ }^{1}$ Basing on the $\mathrm{e}_{\text {ref }}$ values (given in square brackets) and electron microprobe data we consider these occupancies of the sites, taking into account coordination polyhedra character and interatomic distances.

${ }^{2} U_{\text {iso. }}$

${ }^{3}$ Atom coordinates of the P' site are fixed

${ }^{4}$ Multiplicities of the $\mathrm{Cu}(2)$ is 1 , multiplicities of all other sites are 2.

${ }^{5}$ Values were fixed on the last stages of the refinement.

${ }^{6}$ BVS have been formally calculated taking into account s.o.f.

${ }^{7} \mathrm{BVS}$ to $\mathrm{O}(13)$ and $\mathrm{O}\left(13^{\prime}\right)$ are given as for full-occupied sites

${ }^{8}$ See the text
}

initial lomonosovite (Fig. 5b). The $\mathrm{Na}$ (i) site contains $\mathrm{Na}, \mathrm{Ca}$ and vacancies $\left(\mathrm{e}_{\mathrm{ref}}=11.2\right)$ whereas $\mathrm{Na}(\mathrm{o})$ hosts $\mathrm{Na}$ and vacancies $\left(\mathrm{e}_{\text {ref }}=6.5\right.$, Table 11). The $\mathrm{Cu}^{2+}$ cations occupy two crystallographically independent positions. The $\mathrm{Cu}(1)$ site, corresponding to the $\mathrm{Na}(3)$ site in the initial lomonosovite, is located in a cavity in the interlayer space under the square window in the $H$ sheet. It is occupied solely by $\mathrm{Cu}^{2+}(79 \%$ of site occupancy) with the average $<\mathrm{Cu}(1)-\mathrm{O}>$ distance of $2.18 / 2.17 \AA$ [calculated for polyhedra with the bonds $\mathrm{Cu}(1)-\mathrm{O}(13) / \mathrm{Cu}(1)-\mathrm{O}\left(13^{\prime}\right)$, respectively]. The low-occupancy $\mathrm{Cu}(2)$ site is located in the inversion centre in the $O$ sheet; this site is vacant in the initial lomonosovite. $\mathrm{The} \mathrm{Cu}(2)$ cation is surrounded by six $\mathrm{O}$ atoms forming an octahedron distorted due to the Jahn-Teller effect. It has four short $\mathrm{Cu}-\mathrm{O}$ distances [two of 1.778(9) and two of 1.816(9) $\AA$ ] and two elongated $\mathrm{Cu}-\mathrm{O}(1)$ bonds of 2.640(12) $\AA$ (Table 12). Sodium in the $\mathrm{Na}(\mathrm{o})$ position has to be partially substituted for $\mathrm{O}$ which is a ligand to a $\mathrm{Cu}(2)$ site (Fig. 8) and the $\mathrm{Cu}(2)$ site hosts $\mathrm{Cu}$ only when the $\mathrm{Na}(1)$ site is occupied by $\mathrm{O}$.

The $\mathrm{Cu}$-exchanged form of lomonosovite demonstrates a splitting of the P site along $a$ into the two subsites $\mathrm{P}$ and
$\mathrm{P}^{\prime}$. The occupancies have been refined to $68 \%(\mathrm{P})$ and 21 $\%$ (P'), respectively. Thus $\mathrm{PO}_{4}$ tetrahedra have two possible orientations, with splitting of one apical site into two subsites: $\mathrm{O}(13)$ and $\mathrm{O}\left(13^{\prime}\right)$ with the occupancies 69 and 32 $\%$ for $\mathrm{PO}_{4}$ - and $\mathrm{P}^{\prime} \mathrm{O}_{4}$-tetrahedra, respectively.

The total site occupancy factor for $\mathrm{P}$ sites shows that ion exchange is accompanied by a slight hydration according to the scheme $3 \mathrm{Na}^{+}+\mathrm{PO}_{4}{ }^{3-} \rightarrow x \mathrm{H}_{2} \mathrm{O}+\square$, the same as in the case of the Ag-exchanged form of lomonosovite. The bond-valence sums for anion sites coordinating the $\mathrm{P}$ and $\mathrm{P}^{\prime}$, namely $\mathrm{O}(10), \mathrm{O}(11), \mathrm{O}(12), \mathrm{O}(13)$ and $\mathrm{O}\left(13^{\prime}\right)$ are $1.83,1.70,1.43,1.36$ and $1.50 v u$, respectively (Table 11). This indicates the admixture of $\mathrm{H}_{2} \mathrm{O}$ or $\mathrm{OH}^{-}$ which could occupy these sites when $\mathrm{P}$ and $\mathrm{P}$ ' sites are vacant, as in the Ag-exchanged form of lomonosovite. It is confirmed by the appearance of absorption bands of $\mathrm{O}-\mathrm{H}$ stretching vibrations (at 3220 and $3440 \mathrm{~cm}^{-1}$ ) and $\mathrm{H}-\mathrm{O}-\mathrm{H}$ bending vibrations (at $1650 \mathrm{~cm}^{-1}$; Fig. 7) in the IR spectrum of the $\mathrm{Cu}$-exchanged form of lomonosovite. Like the previous case, there is no evidence of the presence of $\mathrm{PO}_{3} \mathrm{OH}$ groups.

Some positive charge deficiency in the $\mathrm{HOH}$ block caused by leaching of $\mathrm{Na}$ from both $O$ and $H$ sheets is 
Table 12. Selected interatomic distances $(\AA)$ for $\mathrm{Cu}$-exchanged form of lomonosovite.

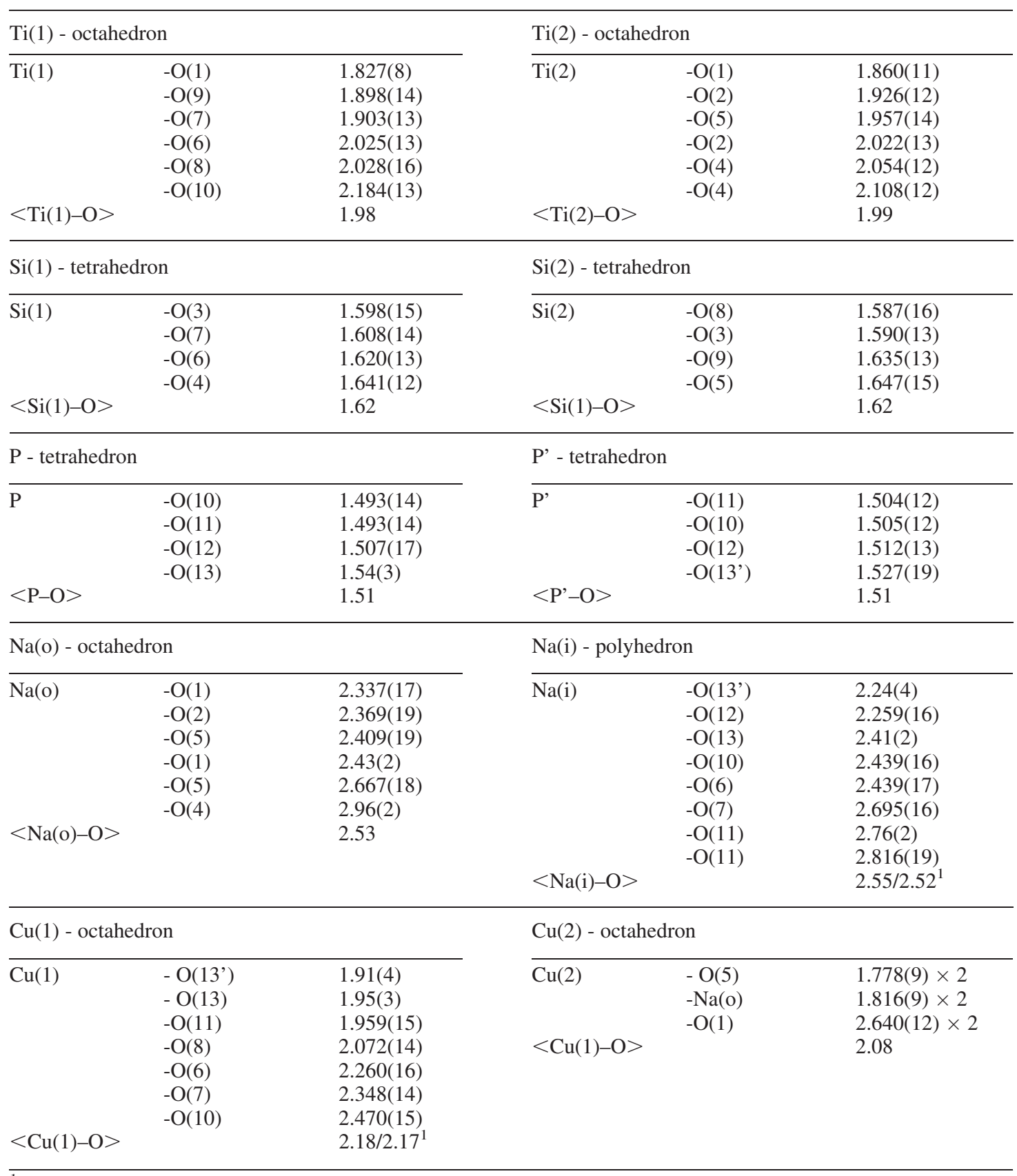

${ }^{1}$ Calculated for polyhedra with bonds $M-\mathrm{O}(13) / M-\mathrm{O}\left(13^{\prime}\right)$

compensated by partial protonation of the $\mathrm{Ti}(2)-\mathrm{O}-$ $\mathrm{Ti}(2)$ bridge oxygen $\mathrm{O}(2)$. The bond-valence sum for $\mathrm{O}(2)$ is $1.56 v u$. It is confirmed by the appearance of absorption bands at 3491 and $3575 \mathrm{~cm}^{-1}$ in the IR spectrum of the $\mathrm{Cu}$-exchanged form of lomonosovite, corresponding to $\mathrm{O}-\mathrm{H}$ stretching vibrations of basic $\mathrm{OH}$ groups (Fig. 7).

The formula of the Cu-exchanged form of lomonosovite obtained from the structural refinement is $\left\{\mathrm{Cu}_{1.58} \mathrm{Na}_{1.30} \mathrm{Ca}_{0.40}\right\}\left\{\mathrm{Na}_{1.04} \mathrm{Cu}_{0.1}\left(\mathrm{Ti}_{1.24} \mathrm{Mn}_{0.60} \mathrm{Nb}_{0.16}\right)\right\}\left\{\mathrm{Ti}_{2.00}\right.$ $\left.\left[\mathrm{Si}_{2} \mathrm{O}_{7}\right]_{2}\right\} \mathrm{O}_{2}(\mathrm{O}, \mathrm{OH})_{2}\left(\mathrm{PO}_{4}\right)_{1.78}\left(\mathrm{H}_{2} \mathrm{O}\right)_{\mathrm{x}}$, in which the contents of the interlayer space, $O$ and $H$ sheets are correspondingly given in braces. It is in agreement with the electron microprobe data (Table 1).

\section{Conclusions}

Murmanite and lomonosovite show strong ion-exchange capacity for chalcophile elements, $\mathrm{Ag}$ and $\mathrm{Cu}$. These cations can occupy the positions in the interlayer space, $O$ and $H$ sheets whereas the general topology of the main 


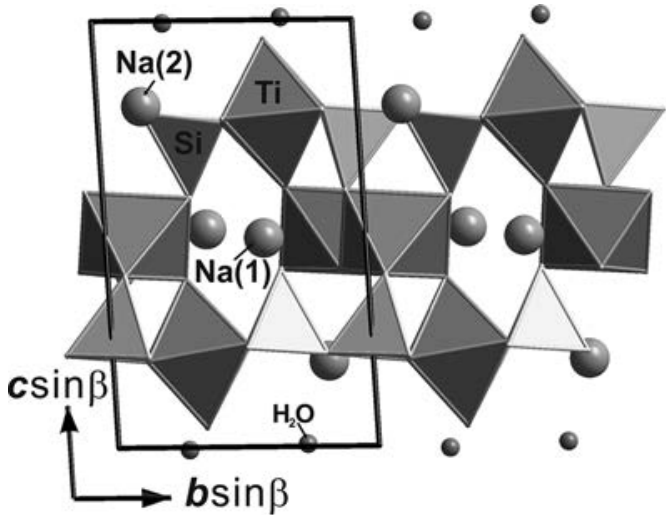

a)

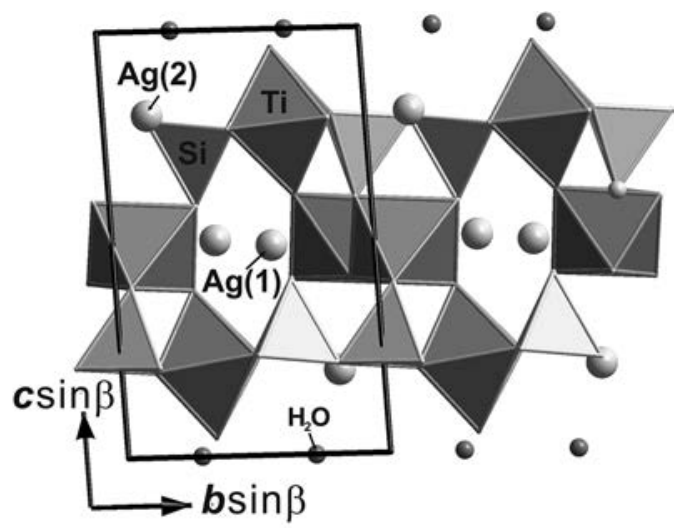

b)

Fig. 3. The crystal structure of murmanite (a) and its Ag-exchanged form (b) projected along $a$. The unit cells are outlined.

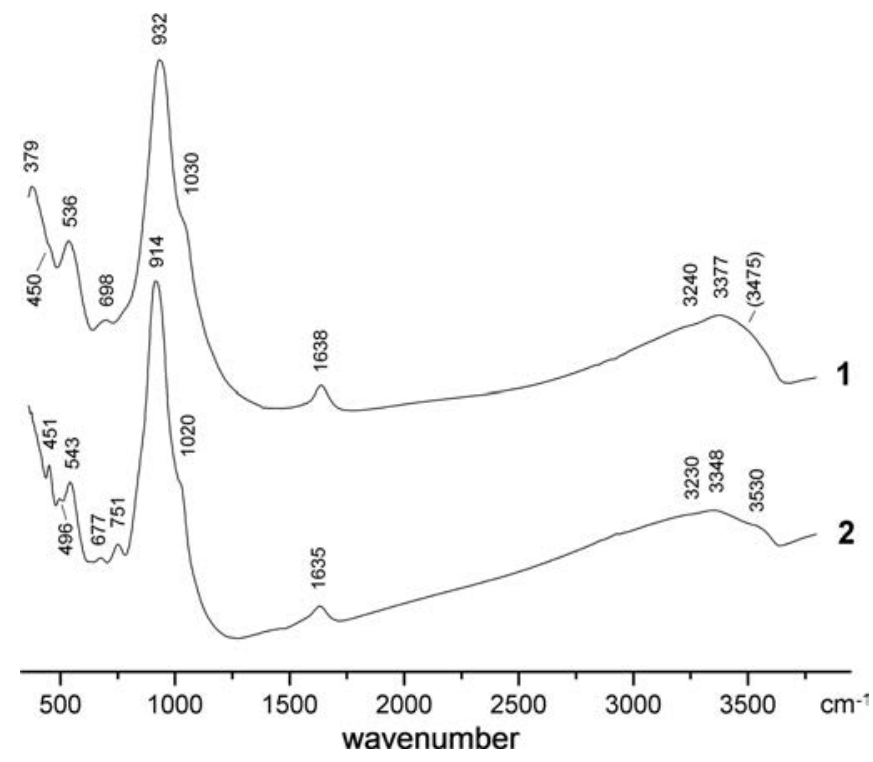

Fig. 4. IR spectra of murmanite (1) and the product of its ion exchange with $1 \mathrm{~N} \mathrm{AgNO}_{3}$ solution at $90^{\circ} \mathrm{C}$ during 5 hours (2). heteropolyhedral $\mathrm{HOH}$ block remains unchanged in all cases. This allows us to consider the heterophyllosilicates murmanite and lomonosovite as natural microporous materials that are cation exchangers with mobile $\mathrm{Na}$ cations in both the interlayer space (a 2D system of channels) and the $\mathrm{HOH}$ block. As their combination, a 3D system of channels appears.

In both compounds $\mathrm{Ag}^{+}$replaces $\mathrm{Na}^{+}$or fills vacancies at all large cation sites. The $\mathrm{Cu}^{2+}$ cations in the $\mathrm{Cu}$ exchanged form of lomonosovite occupy one site in the interlayer space, corresponding to one of the three $\mathrm{Na}$ sites in the initial lomonosovite, and one low-occupancy site in the $O$ sheet (on the inversion centre). The latter site centers an octahedron with Jahn-Teller elongation, as for many other $\mathrm{Cu}^{2+}$ compounds. The exchange of $\mathrm{Na}^{+}$for $\mathrm{Cu}^{2+}$ is accompanied by leaching of $\mathrm{Na}$ from the two other sites in the interlayer space of lomonosovite to form a cationdeficient phase with vacancies in all large-cation sites. The $\mathrm{Ca}^{2+}$ ion, partially substituting $\mathrm{Na}^{+}$in the initial murmanite and lomonosovite, is rigidly fixed in their structures and is almost inert during the exchange.

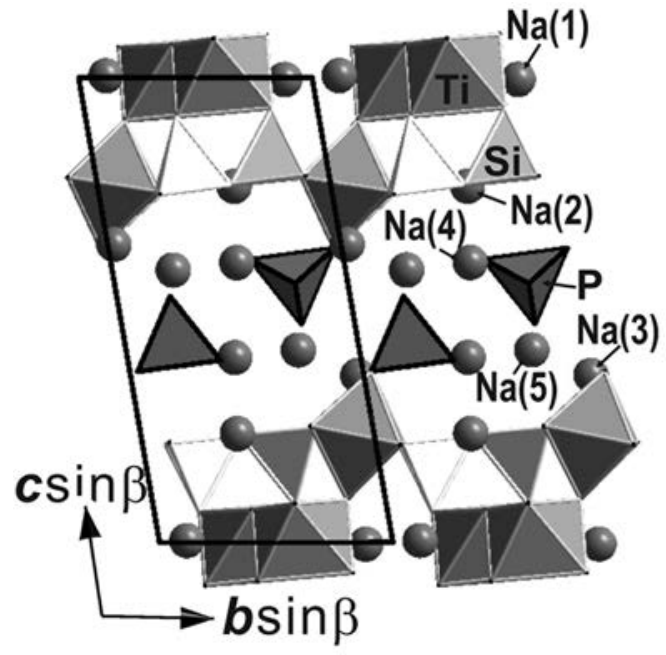

a)



b)

Fig. 5. The crystal structure of lomonosovite (a) and its $\mathrm{Cu}$-exchanged form (b) projected along $a$. Large-cation sites are shown as circles. The unit cells are outlined 


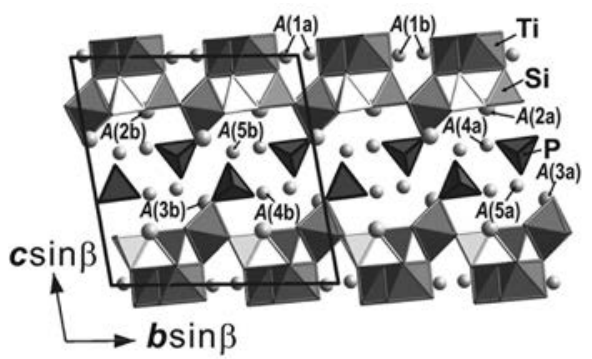

a)



b)

Fig. 6. The crystal structure of the Ag-exchanged form of lomonosovite projected along $a$ (a) and $c$ (b). Large-cation sites are shown as circles. The unit cell is outlined.

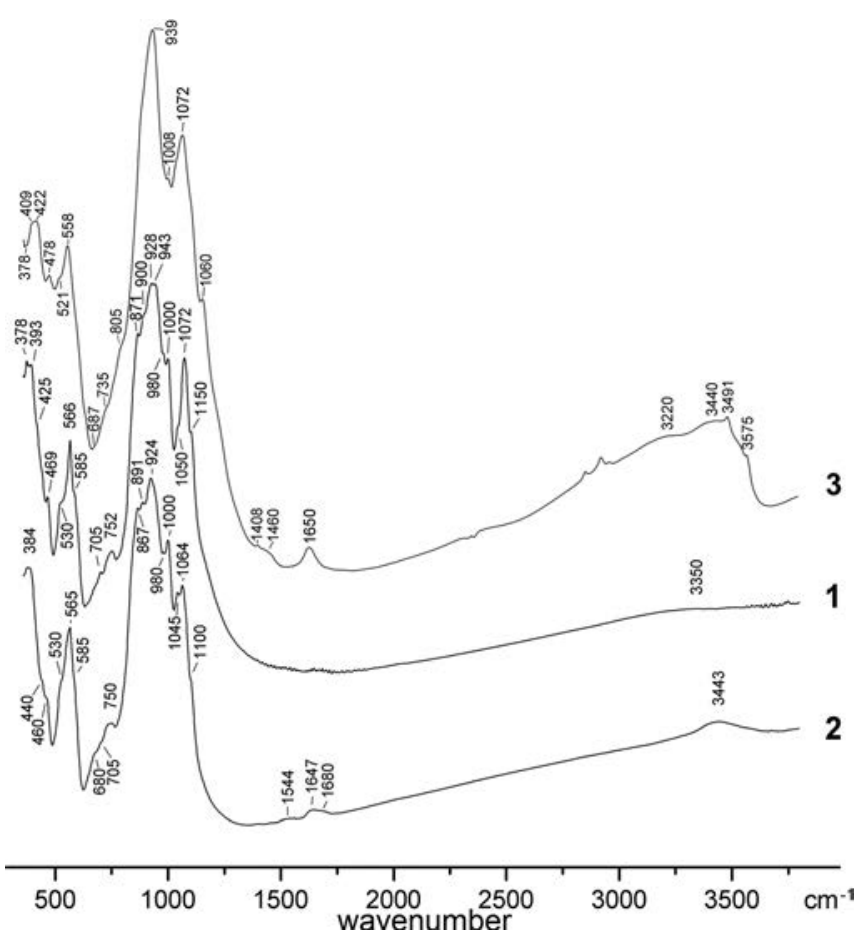

Fig. 7. IR spectra of lomonosovite (1), the product of its ion exchange with $1 \mathrm{~N} \mathrm{AgNO}_{3}$ solution during 72 hours (2) and with $1 \mathrm{~N} \mathrm{CuSO}_{4}$ solution during 28 hours (3) at $150^{\circ} \mathrm{C}$.



Fig. 8. The $O$ sheet in the crystal structure of the $\mathrm{Cu}$-exchanged form of lomonosovite.
Charge deficiency of cation-exchanged phases (caused by filling vacancies by $\mathrm{Ag}^{+}$or, in case of the reaction with $\mathrm{Cu}^{2+}$, leaching of $\mathrm{Na}^{+}$) is compensated by protonation/ deprotonation of the bridging $\mathrm{O}$ atom in Ti-O-Ti.

Ion-exchange in the $\mathrm{PO}_{4}$-bearing heterophyllosilicate lomonosovite is accompanied by its slight hydration according to the scheme $3 \mathrm{Na}^{+}+\mathrm{PO}_{4}{ }^{3-} \rightarrow x \mathrm{H}_{2} \mathrm{O}+\square$.

Ion exchange in lomonosovite results in the splitting of the $\mathrm{P}$ site in the interlayer space to form two $\mathrm{P}$ sites, statistically occupying two tetrahedra with $50 \%$ occupancy. There are two crystallographically nonequivalent $\mathrm{P}$ positions in the Ag-exchanged form of lomonosovite instead of one site in the initial lomonosovite. Additionally, one of these sites is split that causes doubling of the $b$ parameter and, consequently, the unit-cell volume. Splitting of both or only of the $\mathrm{P}$ sites in the interlayer space is clearly dependent on the type of exchangable cation, but the cause of it is still the subject of further examination.

Acknowledgements: We are grateful to Gerald Giester for his help in XRD data collection and Olga V. Yakubovich for fruitful discussion. We thank Péter Németh and anonymous referee for their valuable comments and Sergey V. Krivovichev for his editorial work. This work was supported by Russian Foundation for Basic Research, grants nos. 12-0590831-mol_rf_nr, 12-05-31212-mol_a, 13-05-12021_ofi_m and 14-05-00190-a, and by the Foundation of the President of the Russian Federation, grants nos. NSh-1130.2014.5 and MD-2088.2014.5. The support by the SPbSU X-Ray Diffraction Resource Center is acknowledged.

\section{References}

Belov, N.V., Gavrilova, G.S., Solov'eva, L.P., Khalilov, A.D (1977): The refined structure of lomonosovite. Sov. Phys. Dokl., 235, 1064-1067. (in Russian)

Borneman-Starynkevich, I.D (1946): On chemical nature of murmanite. in "Problems of Mineralogy, Geochemistry and Petrography" (Ed. D.S. Belyankin), AN USSR, MoscowLeningrad, 66-74. (in Russian)

Brese, N.E. \& O'Keeffe, N.E (1991): Bond-valence parameters for solids. Acta Crystallogr., 47, 192-197. 
Cámara, F., Sokolova, E., Hawthorne, F.C., Abdu, Y (2008): From structure topology to chemical composition. IX. Titanium silicates: revision of the crystal chemistry of lomonosovite and murmanite, Group-IV minerals. Mineral. Mag., 72, 1207-1228.

Chukanov, N.V. \& Pekov, I.V (2005): Heterosilicates with tetrahedral-octahedral frameworks: mineralogical and crystal-chemical aspects. Rev. Mineral. Geochem., 57, 105-143.

Ferraris, G. \& Gula, A (2005): Polysomatic aspects of microporous minerals - heterophyllosilicates, palysepioles and rhodesiterelated structures. Rev. Mineral. Geochem., 57, 69-104.

Gerasimovsky, V.I. (1945): Mineralogy of the Lovozero Alkaline Massif. Dr. Sci. thesis. Moscow, 258 p. (in Russian).

- (1950): Lomonosovite, a new mineral. Dokl. Akad. Nauk SSSR, 70, 83-86. (in Russian)

Gutkova, N.N (1930): A new titano-silicate - murmanite from Lovozero tundras. Dokl. Akad. Nauk SSSR, ser. A, 27, 731-736. (in Russian)

Khalilov, A.D (1989): The refinement of murmanite crystal structure and new data on its crystallo-chemical features. Mineral. J., 11, 19-27. (in Russian)

Khalilov, A.D., Makarov, E.S., Mamedov, Kh., P'yanzina, S, Ya, L (1965): On the crystal structure of minerals of the murmanite-lomonosovite group. Dokl. Akad. Nauk SSSR, 162, 179-182. (in Russian)

Khomyakov, A.P (1995): Mineralogy of hyperagpaitic alkaline rocks. Clarendon Press, Oxford, 223 p.

Lykova, I.S., Chukanov, N.V., Tarasov, V.P., Pekov, I.V., Yapaskurt, V.O (2013a): Ion exchange properties of murmanite $\mathrm{Na}_{2} \mathrm{Ti}_{2}\left(\mathrm{Si}_{2} \mathrm{O}_{7}\right) \mathrm{O}_{2} \cdot 2 \mathrm{H}_{2}$ O. Russ. J. Phys. Chem. B Focus Phys., 32, 35-42. (in Russian)
Lykova, I.S., Chukanov, N.V., Kazakov, A.I., Tarasov, V.P., Pekov, I.V., Yapaskurt, V.O., Chervonnaya, N.A (2013b): Murmanite and lomonosovite as Ag-selective ionites: kinetics and products of ion exchange in aqueous $\mathrm{AgNO}_{3}$ solutions. Phys. Chem. Minerals, 40, 625-633.

Németh, P., Ferraris, G., Radnóczi, G., Ageeva, O.A (2005): TEM and X-ray study of syntactic intergrowths of epistolite, murmanite and shkatulkalite. Can. Mineral., 43, 973-998.

Pekov, I.V. \& Chukanov, N.V (2005): Microporous framework silicate minerals with rare and transition elements: minerogenetic aspects. Rev. Mineral. Geochem., 57, 145-171.

Ramsay, W (1890): Geologische Beobachtungen auf der Halbinsel Kola. Nebst einem Anhange: Petrographische Beschreibung der Gesteine des Lujavr-urt. Fennia, 3, 1-52.

Rastsvetaeva, R.K. \& Andrianov, V.N (1986): New data on the crystal structure of murmanite. Kristallografiya, 31, 82-87. (in Russian)

Rastsvetaeva, R.K., Simonov, V.I., Belov, N.V (1971): The crystal structure of lomonosovite. Dokl. Akad. Nauk SSSR, 197, 81-84. (in Russian)

Selivanova, E.A. (2012): The exchange processes and evolution of titanosilicates in the Kibiny and Lovozeto alkaline massifs. Dissertation, Saint-Petersburg State University (in Russian).

Sheldrick, G.M (2008): A short history of SHELX. Acta Crystallogr., A64, 112-122.

Received 29 August 2014

Modified version received 22 January 2015

Accepted 26 February 2015 